\title{
Kinetic and Spectroscopic Evidence for Reaction Pathways and Intermediates for Olefin Epoxidation on $\mathrm{Nb}$ in *BEA
}

\author{
Daniel T. Bregante ${ }^{1}$, Pranjali Priyadarshini ${ }^{1}$, and David W. Flaherty ${ }^{1, *}$ \\ ${ }^{1}$ Department of Chemical and Biomolecular Engineering \\ University of Illinois Urbana-Champaign, Urbana, IL 61801
}

*Corresponding Author

Phone: (217) 244-2816

Email: dwflhrty@illinois.edu 
Graphical Abstract - TOC

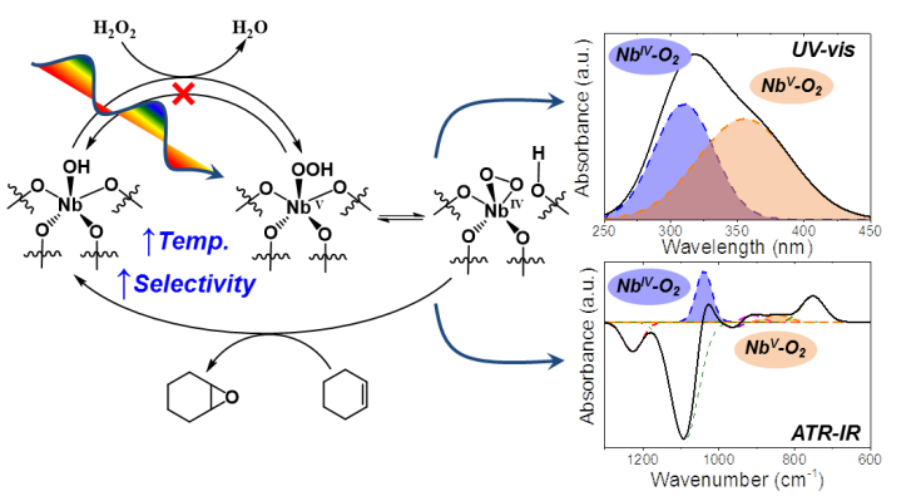




\begin{abstract}
The selective epoxidation of olefins with hydrogen peroxide $\left(\mathrm{H}_{2} \mathrm{O}_{2}\right)$ over transition metal substituted zeolites is less environmentally impactful than epoxidation schemes that use chlorinated or organic oxidants. The structure and reactivity of reactive intermediates derived from $\mathrm{H}_{2} \mathrm{O}_{2}$ and the mechanism for olefin epoxidation on such materials are debated. Here, cyclohexene oxide formation and $\mathrm{H}_{2} \mathrm{O}_{2}$ decomposition rates (measured as functions of reactant and product concentrations) and in situ infrared (IR) and UV-vis spectroscopy are used to probe the intervening elementary steps for cyclohexene $\left(\mathrm{C}_{6} \mathrm{H}_{10}\right)$ epoxidation and the identity of the reactive intermediates on a $\mathrm{Nb}-\beta$ catalyst. IR and UV-vis spectra acquired in situ show that the reactive intermediates are predominantly superoxide species $\left(\mathrm{Nb}^{\mathrm{IV}}-\left(\mathrm{O}_{2}\right)^{-}\right.$; observed also by X-ray photoelectron spectroscopy), which form by the irreversible activation of $\mathrm{H}_{2} \mathrm{O}_{2}$ over $\mathrm{Nb}$ centers. Similar $\mathrm{M}-\left(\mathrm{O}_{2}\right)^{*}(\mathrm{M}=\mathrm{Ti}$ or $\mathrm{Ta})$ intermediates were previously assumed to form via reversible processes; however, in situ IR and UV-vis measurements directly show that $\mathrm{Nb}^{\mathrm{IV}}-\left(\mathrm{O}_{2}\right)^{-}$forms irreversibly in both $\mathrm{H}_{2} \mathrm{O}$ and acetonitrile. Activation enthalpies $\left(\Delta \mathrm{H}^{*}\right)$ for $\mathrm{C}_{6} \mathrm{H}_{10}$ epoxidation are $27 \mathrm{~kJ} \mathrm{~mol}^{-1}$ higher than for $\mathrm{H}_{2} \mathrm{O}_{2}$ decomposition, while activation entropies $\left(\Delta \mathrm{S}^{\ddagger}\right)$ for epoxidation are $56 \mathrm{~J} \mathrm{~mol}^{-1} \mathrm{~K}^{-1}$ lower than for $\mathrm{H}_{2} \mathrm{O}_{2}$. These comparisons show that the selectivities for epoxidation, via primary reaction pathways, increase with increasing reaction temperatures. Collectively, these results provide a self-consistent mechanism for $\mathrm{C}_{6} \mathrm{H}_{10}$ epoxidation that is also in agreement with previously published data. These findings will aid the rational design and study of alternative metal oxide catalysts for olefin oxidation reactions.
\end{abstract}

Keywords: olefin epoxidation, zeolites, niobium, in situ spectroscopy, metal oxide catalysis, green chemistry, hydrogen peroxide 


\subsection{Introduction}

Epoxides are important precursors for the synthesis of epoxy resins, plastics, and complex molecules used to manufacture aircraft hulls, perfumes, and pharmaceuticals [1-3]. Currently, epoxides are produced primarily by the reaction of olefins with stoichiometric amounts of organic peroxy compounds [4] or through chlorohydrin intermediates followed by strong alkaline treatments to form oxiranes $[5,6]$. These processes generate stoichiometric amounts of corrosive organic acids and alcohols [7] or chloride salts [5], respectively, that require subsequent energy-intensive separation, waste-treatment, and regeneration [8, 9]. More environmentally benign oxidants should be used; however, the costs of "green" oxidants that generate less waste are generally greater and the product selectivities may be lower than $\mathrm{Cl}$ mediated pathways $[10,11]$. Hydrogen peroxide $\left(\mathrm{H}_{2} \mathrm{O}_{2}\right)$ is one such oxidant whose use only byproduct in epoxidation reactions is water $\left(\mathrm{H}_{2} \mathrm{O}\right)$, which is easily separated from organic product streams by liquid-liquid extraction $[12,13]$. Currently, the high relative cost of $\mathrm{H}_{2} \mathrm{O}_{2}$ (to that of Cl-based oxidizers) requires catalysts that selectively activate and utilize $\mathrm{H}_{2} \mathrm{O}_{2}$ for olefin epoxidation while minimizing non-productive $\mathrm{H}_{2} \mathrm{O}_{2}$ decomposition (i.e., $2 \mathrm{H}_{2} \mathrm{O}_{2} \rightarrow \mathrm{O}_{2}+2 \mathrm{H}_{2} \mathrm{O}$ ) and epoxide decomposition.

Isolated metal centers and small oligomers of early transition metal oxides (e.g., $\mathrm{Al}^{\mathrm{III}}[14$, 15], $\mathrm{Ti}^{\mathrm{IV}}$ [7, 16-18], $\mathrm{Zr}^{\mathrm{IV}}[19,20], \mathrm{Ta}^{\mathrm{V}}$ [21-23], and $\left.\mathrm{Nb}^{\mathrm{V}}[24,25]\right)$ catalyze the epoxidation of olefins with $\mathrm{H}_{2} \mathrm{O}_{2}$. Isolated $\mathrm{Nb}$ atoms grafted onto silica give greater rates and selectivities for olefin epoxidation compared to isolated Ti centers as well those of other group IV and V metals (i.e., Zr, Hf, V, and Ta) on silica, which was attributed to differences between the Lewis acidity (estimated from the ionic character of the M-O bond) of the different metal atoms [20]. Zeolite frameworks can stabilize relatively high loadings of isolated transition metal atoms [26-30], 
which in some cases, are believed to possess higher turnover rates ((mol product)(mol active site $\cdot \mathrm{s}^{-1}$ ) and selectivities than their oligomeric- and bulk-oxide counterparts. For example, Ti centers in titania silicalite (TS-1) activate $\mathrm{H}_{2} \mathrm{O}_{2}$ to form intermediates that epoxidize propylene in one of few industrially practiced $\mathrm{H}_{2} \mathrm{O}_{2}$-based oxidation reactions [31-33]. TS-1, however, possesses relatively small diameter pores ( $5 \AA$, due to the MFI framework) [34], which hinders the diffusion of larger olefins (e.g., cyclooctene, limonene, etc.) [31, 35] to Ti centers within the pores. Larger pore zeolite frameworks, such as the beta (*BEA) polymorph, possess pores with diameters of $\sim 7 \AA$ [34], which broadens the range of potential substrates for epoxidations [36]. Post-synthetic modification of *BEA and other zeolites provides a facile method to synthesize transition metal substituted catalysts using commercially-available zeolites as precursors [26, 27, 36, 37], which enables studies of how the elemental identity of isolated metal centers in similar coordination environments affects catalysis [38]. As such, the mechanism of olefin epoxidation on transition metal substituted *BEA (M- $\beta$ ) must be established before such periodic trends can be understood.

Here, we combine catalytic rate measurements with in situ UV-vis and Fourier transforminfrared (FTIR) spectra to determine the mechanism for cyclohexene epoxidation and the structure and reactivity of relevant reaction intermediates on Nb- $\beta$. In situ UV-vis and IR spectroscopy show $\mathrm{Nb}$-bound superoxide $\left(\mathrm{Nb}^{\mathrm{IV}}-\left(\mathrm{O}_{2}\right)^{-}\right)$and hydroperoxide/peroxide $\left(\mathrm{Nb}^{\mathrm{V}}-\mathrm{OOH}\right.$ and $\left.\mathrm{Nb}^{\mathrm{V}}-\left(\mathrm{O}_{2}\right)^{2-}\right)$ intermediates form by irreversible activation of $\mathrm{H}_{2} \mathrm{O}_{2}$ at $\mathrm{Nb}$-atoms, which conflicts with proposed mechanisms for olefin epoxidation on similar catalysts (i.e., TS-1 [39], Ta-SBA-15 [21, 40], and $\mathrm{Ta}_{-} \mathrm{SiO}_{2}[22,23]$ ) that assume reversible (and quasi-equilibrated) $\mathrm{H}_{2} \mathrm{O}_{2}$ activation. X-ray photoelectron spectroscopy of $\mathrm{H}_{2} \mathrm{O}_{2}$-activated $\mathrm{Nb}-\beta$ confirms the presence of $\mathrm{Nb}^{\mathrm{IV}}-\left(\mathrm{O}_{2}\right)^{-}$surface species by showing that $\mathrm{Nb}$ atoms shift from a $5+$ to $4+$ oxidation state when 
activated with $\mathrm{H}_{2} \mathrm{O}_{2}$. A combination of transient in situ UV-vis and FTIR measurements demonstrate that the $\mathrm{Nb}^{\mathrm{IV}}-\left(\mathrm{O}_{2}\right)^{-}$specie is the active oxidizing intermediate for epoxidation and possesses a rate constant for epoxidation that is a factor of $2 \cdot 10^{4}$ larger than that for $\mathrm{Nb}^{\mathrm{V}}$ $\mathrm{OOH} / \mathrm{Nb}^{\mathrm{V}}-\left(\mathrm{O}_{2}\right)^{2-}$.

Turnover rates $\left((\mathrm{mol}\right.$ product $\left.)(\mathrm{mol} \mathrm{Nb} \text { atom } \cdot \mathrm{s})^{-1}\right)$ were measured as functions of the concentrations of $\mathrm{C}_{6} \mathrm{H}_{10}(0.01-5 \mathrm{M}), \mathrm{H}_{2} \mathrm{O}_{2}(0.5-5 \mathrm{mM})$, and cyclohexene oxide $\left(\mathrm{C}_{6} \mathrm{H}_{10} \mathrm{O}, 1-5\right.$ $\mathrm{mM}$ ). Formation rates of $\mathrm{C}_{6} \mathrm{H}_{10} \mathrm{O}$ increase in proportion to $\left[\mathrm{C}_{6} \mathrm{H}_{10}\right]$ but become constant at high $\left[\mathrm{C}_{6} \mathrm{H}_{10}\right]$ values. The rate of epoxidation is independent of $\left[\mathrm{H}_{2} \mathrm{O}_{2}\right]$ when $\left[\mathrm{C}_{6} \mathrm{H}_{10}\right]$ is low, but becomes proportional to $\left[\mathrm{H}_{2} \mathrm{O}_{2}\right]$ at high $\left[\mathrm{C}_{6} \mathrm{H}_{10}\right]$. These results reflect the competitive adsorption of $\mathrm{H}_{2} \mathrm{O}_{2}$ - and $\mathrm{C}_{6} \mathrm{H}_{10}$-derived species, which results in a change in the most abundant reactive intermediate (MARI) on Nb-sites. Upon formation of $\mathrm{Nb}^{\mathrm{IV}}-\left(\mathrm{O}_{2}\right)^{-}$, the intermediate reacts either with $\mathrm{C}_{6} \mathrm{H}_{10}$ or $\mathrm{H}_{2} \mathrm{O}_{2}$ to form the epoxidation (i.e., cyclohexene oxide) or decomposition products (i.e., $\mathrm{H}_{2} \mathrm{O}$ and $\left.\mathrm{O}_{2}\right)$, respectively. Measured activation enthalpies $\left(\Delta \mathrm{H}^{\star}\right)$ for epoxidation $(72 \mathrm{~kJ}$ $\mathrm{mol}^{-1}$ ) and $\mathrm{H}_{2} \mathrm{O}_{2}$ decomposition $\left(45 \mathrm{~kJ} \mathrm{~mol}^{-1}\right.$ ) show that decomposition is enthalpically favorable, whereas activation entropies $\left(\Delta \mathrm{S}^{\ddagger},-35 \mathrm{~J} \mathrm{~mol}^{-1} \mathrm{~K}^{-1}\right.$ for $\mathrm{C}_{6} \mathrm{H}_{10} \mathrm{O}$ formation and $-91 \mathrm{~J} \mathrm{~mol}^{-1} \mathrm{~K}^{-1}$ for $\mathrm{H}_{2} \mathrm{O}_{2}$ decomposition) suggest that epoxidation is entropically favorable. Collectively, these data provide insight to the identity of the reactive surface species responsible for epoxidations and the mechanism for this reaction on transition metal substituted zeolites, which is needed to understand the underlying chemical reasons that lead to significant differences in rates and selectivities that reflect the elemental identity of the transition metal atoms that facilitate oxidation reactions.

\subsection{Methods and Materials Characterization}

\subsection{Synthesis of Nb- $\beta$ Catalysts}


Niobium-substituted zeolite catalysts were prepared by the post-synthetic modification of commercial zeolite beta $[26,27]$. Commercial *BEA (Zeolyst, Si:Al 12.5, $\mathrm{NH}_{4}{ }^{+}$cation, Al- $\beta$ ) was dealuminated by treatment with concentrated $\mathrm{HNO}_{3}$ (Macron Chemicals, $69-70$ wt. \%, 20 $\mathrm{cm}^{3}$ per gram of zeolite) at reflux (448 K) for $20 \mathrm{~h}$. Slurries of Al- $\beta$ and $\mathrm{HNO}_{3}$ are initially a dark brown color, but the color of these suspensions change to a light tan after four hours at reflux. The dealuminated zeolite (Si- $\beta$, Si:Al $>1200$ determined by inductively couple plasma - optical emission spectroscopy) was then recovered by filtration and washed with concentrated $\mathrm{HNO}_{3}(10$ $\left.\mathrm{cm}^{3} \mathrm{~g}^{-1}\right)$ followed by deionized (DI) water $\left(17.8 \mathrm{M} \Omega, 20 \mathrm{~cm}^{3} \mathrm{~g}^{-1}\right)$. The wet recovered Si- $\beta$ solids were dried in an oven within ambient air for 18 hours at $423 \mathrm{~K}$. The dried solids were then heated to $823 \mathrm{~K}$ at $5 \mathrm{~K} \mathrm{~min}^{-1}$ and held at $823 \mathrm{~K}$ for 6 hours in flowing dry air (Airgas, Ultra-zero grade, $100 \mathrm{~cm}^{3} \min ^{-1}$ ) with the intent to remove residual organics from the $\mathrm{Si}-\beta$. Nb atoms were incorporated into the framework by liquid-phase adsorption (LPA), which involved stirring Si- $\beta$ in a $0.35-3.5 \mathrm{mM}$ solution of $\mathrm{NbCl}_{5}$ (Sigma-Aldrich, $99 \%, 50 \mathrm{~cm}^{3} \mathrm{~g}^{-1}$ ) in isopropyl alcohol (VWR Analytical, > 99.5\%) for 6 hours at $343 \mathrm{~K}$. Volatiles were then removed in vacuo at 6.6 $\mathrm{kPa}$ for 30 minutes followed by washing with $75 \mathrm{~cm}^{3} \mathrm{~g}^{-1}$ DI water with the intent to remove any residual $\mathrm{NbCl}_{5}$ not exchanged into defects within the framework. The recovered solids were heated to $723 \mathrm{~K}$ at $5 \mathrm{~K} \mathrm{~min}^{-1}$ and held at $723 \mathrm{~K}$ for 4 hours in flowing dry air (Airgas, Ultra-zero grade, $100 \mathrm{~cm}^{3} \mathrm{~min}^{-1}$ ) to yield a white powder. Nb-substituted zeolites are referred to as $\mathrm{Nb}_{\mathrm{X}}-\beta$ where the subscript denotes the final wt. \% of $\mathrm{Nb}(0.15-5.0$ wt. \%), which was controlled by changing the concentrations of $\mathrm{NbCl}_{5}$ and $\mathrm{Si}-\beta$ in the LPA solution.

A 10 wt. $\% \mathrm{Nb}-\mathrm{SiO}_{2}\left(\mathrm{Nb}_{10}-\mathrm{SiO}_{2}\right)$ catalyst was prepared by incipient wetness impregnation of washed $\mathrm{SiO}_{2}\left(1 \mathrm{~g}\right.$, Sigma-Aldrich, Davisil 646, 35-60 mesh) with $1.2 \mathrm{~cm}^{3}$ of $0.898 \mathrm{M} \mathrm{NbCl}_{5}$ dissolved in isopropyl alcohol. The catalyst was dried under ambient conditions for $4 \mathrm{~h}$ by 
ramping to $823 \mathrm{~K}\left(5 \mathrm{~K} \mathrm{~min}^{-1}\right)$ for 6 hours under flowing dry air (Airgas, Ultra-zero grade, 100 $\left.\mathrm{cm}^{3} \min ^{-1}\right)$.

\subsection{Catalyst Characterization}

Catalyst metal loadings were quantified using inductively coupled plasma optical emission spectroscopy (ICP-OES, PerkinElmer 2000DV), calibrated against known dilution standards. The reported $\mathrm{Nb}_{\mathbf{x}}-\beta$ subscript corresponds to values measured by ICP-OES.

Catalyst crystallinity was confirmed by powder X-ray diffraction (p-XRD). X-ray diffractograms were obtained using a powder X-ray diffractometer (Siemens/Bruker D-5000) with $\mathrm{Cu} \mathrm{K}-\alpha$ radiation $(0.15418 \mathrm{~nm})$ using a step size of $0.02^{\circ}$ at $1^{\circ} \mathrm{min}^{-1}$ in an ambient atmosphere. X-ray diffractograms for commercial $\mathrm{NH}_{4}{ }^{+}-\beta$, the dealuminated Si- $\beta$, and prepared $\mathrm{Nb}-\beta$ catalysts are effectively indistinguishable (Figure S1). These comparisons show that the post-synthetic modification method does not affect the crystalline structure of the zeolites, and that framework crystallinity is maintained.

Diffuse reflectance UV-vis (DRUV-vis) spectra were measured from 700 to $175 \mathrm{~nm}$ using a spectrophotometer (Agilent CARY 5 UV-Vis-NIR) equipped with a diffuse-reflectance accessory (Harrick Cricket $\left.{ }^{\circledR}\right)$. Spectra were recorded in absolute reflectance $(\mathrm{R})$ mode at ambient pressure and temperature. Magnesium oxide powder (MgO, Sigma Aldrich, 99.995\% trace metals basis) or a polished gallium mirror (Harrick Cricket ${ }^{\circledR}$ ) was used to collect a total reflectance spectrum for use as a baseline for Kubelka-Munk pseudo absorbances (Fig. S2). Nb- $\beta$ and $\mathrm{Nb}-\mathrm{SiO}_{2}$ samples were ground with $\mathrm{MgO}$ (10\% sample by weight) prior to measurement. Optical band gaps $\left(\mathrm{E}_{\mathrm{g}}\right)$ were calculated from the $\mathrm{x}$-intercept of the linear portion of a Tauc plot (Fig. S3) $[20,41]$. Table 1 summarizes the optical band edges of $\mathrm{Nb}-\beta, \mathrm{Nb}_{10}-\mathrm{SiO}_{2}$, bulk $\mathrm{Nb}_{2} \mathrm{O}_{5}$ 
[42], and calixarene-assisted $\mathrm{Nb}$ grafted onto silica $\left(\mathrm{Calix}-\mathrm{Nb}_{1.7}-\mathrm{SiO}_{2}\right)$ [20]. $\mathrm{Nb}_{10}-\mathrm{SiO}_{2}$ has a band edge $(3.7 \mathrm{eV})$ that is similar to that of bulk $\mathrm{Nb}_{2} \mathrm{O}_{5}(3.4 \mathrm{eV})$ [42], which indicates that this material contains metal-oxide clusters with bulk-like electronic properties and sizes of at least several nanometers. All $\mathrm{Nb}-\beta$ catalysts have band edge energies $(4.2 \mathrm{eV})$ that are much larger than that of bulk $\mathrm{Nb}_{2} \mathrm{O}_{5}$ and similar to those previously reported $(4.0 \mathrm{eV})$ for isolated atoms grafted onto mesoporous silica [20]. The similarity between the band gaps for $\mathrm{Nb}_{0.7}-\beta$ and $\mathrm{Nb}_{1.5^{-}}$ $\beta$ strongly suggests that $\mathrm{Nb}$ atoms are incorporated into the zeolite framework as single isolated sites (i.e., the samples contain immeasurable extents of $\mathrm{Nb}-\mathrm{O}-\mathrm{Nb}$ connectivity). If the $\mathrm{Nb}$ atoms were not incorporated into the zeolite framework, but rather forming small clusters, the $\mathrm{NbO}_{\mathrm{x}}$ clusters would become larger with increasing loadings, which would result in a decreasing band gap. Additionally, Fig. S2 shows the Kubelka-Munk absorbance as a function of wavelength for $\mathrm{Nb}_{0.7}-\beta, \mathrm{Nb}_{1.5}-\beta$, and $\mathrm{Nb}_{10}-\mathrm{SiO}_{2}$. Both $\mathrm{Nb}-\beta$ samples show no distinct absorbance feature beyond $\sim 300 \mathrm{~nm}$, which suggests that no extra-framework $\mathrm{Nb}^{\mathrm{V}}$ species exist either as bulk or oligomeric niobia-like phases [26, 43]. 
Table 1. Optical band edges and wavelengths of maximum absorption obtained from diffusereflectance UV-vis spectroscopy Nb-based catalysts. Catalysts were mixed with $\mathrm{MgO}$ in a 1:10 ratio by weight prior to measurement under ambient conditions. Pure $\mathrm{MgO}$ was used as the reference material.

\begin{tabular}{ccc}
\hline Sample & Band Edge (eV) & Maximum Absorption (nm) \\
\hline $\mathrm{Bulk} \mathrm{Nb}_{2} \mathrm{O}_{5}$ & $3.4[42]$ & - \\
$\mathrm{Nb}_{10.0}-\mathrm{SiO}_{2}$ & 3.7 & - \\
Calix- $\mathrm{Nb}_{1.7}-\mathrm{SiO}_{2}$ & $4.0[20]$ & 240 \\
$\mathrm{Nb}_{0.7} \beta$ & 4.2 & 255 \\
$\mathrm{Nb}_{1.5} \beta$ & 4.2 & 255
\end{tabular}

Solid-state magic angle spinning-nuclear magnetic resonance (MAS NMR) spectroscopy was performed on a spectrometer (Varian, Unity Inova $300 \mathrm{MHz}$ ) equipped with a $4 \mathrm{~mm}$ MAS probe (Varian-Chemagnetics, double resonance APEX HX). Approximately $36.4 \mathrm{mg}$ of $\mathrm{Nb}_{1.5}-\beta$ was packed into a $4 \mathrm{~mm}$ zirconia rotor, which was spun at $10 \mathrm{kHz}$ in the spectrometer for MASNMR. Powdered octakis(dimethylsilyloxy)silsesquioxane $\left(\mathrm{Q}_{8} \mathrm{M}_{8}\right)$ was used for pulse calibration and ${ }^{29} \mathrm{Si}$ chemical shift referencing $\left(\mathrm{Q}_{8} \mathrm{M}_{8}\right.$ has a chemical shift of $11.45 \mathrm{ppm}$, relative to the primary standard, tetramethylsilane at $0 \mathrm{ppm}$ ). ${ }^{1} \mathrm{H}$ direct polarization (DP-MAS NMR) was performed with a $10 \mathrm{sec}$ recycle delay with the averaging of 32 scans. ${ }^{1} \mathrm{H} \rightarrow{ }^{29} \mathrm{Si}$ cross polarization (CP-MAS NMR) was performed with a $5 \mathrm{sec}$ recycle delay using an $8 \mathrm{msec}$ contact time with the averaging of 6000 scans. ${ }^{29}$ Si DP-MAS NMR was performed with a 10 sec recycle delay with the averaging of 6000 scans. ${ }^{93} \mathrm{Nb}$ MAS NMR experiments were unsuccessful due to low signal to noise levels even with 69,000 scans with a $1 \mathrm{sec}$ recycle delay.

Figure S4 shows ${ }^{1} \mathrm{H}$ MAS-NMR spectra for $\mathrm{Nb}_{1.5}-\beta$. The lack of a distinct feature located at $5.4 \mathrm{ppm}$ is consistent with the incorporation of $\mathrm{Nb}$ atoms into silanol pockets during postsynthetic modification [43]. Figure S5a shows the ${ }^{29} \mathrm{Si}$ DP-MAS NMR spectra for $\mathrm{Nb}_{1.5}-\beta$, which shows three distinct features at $-102,-112$, and $-115 \mathrm{ppm}$. The feature at $-102 \mathrm{ppm}$ is attributed to 
$\mathrm{Si}$ atoms in a $\mathrm{Si}(\mathrm{OH})(\mathrm{OSi})_{3}$ environment [43-45], while the features at -112 and -115 ppm are assigned to $\mathrm{Si}$ atoms in a $\mathrm{Si}(\mathrm{OM})_{4}$ environment, where $\mathrm{M}=\mathrm{Si}$ or $\mathrm{Nb}$, which are similar to features seen in $\mathrm{Nb}-\beta$ [43], Ta- $\beta$ [45], and $\mathrm{Zr}-\beta$ [44]. Figure S5b shows the ${ }^{1} \mathrm{H} \rightarrow{ }^{29} \mathrm{Si} \mathrm{CP}-\mathrm{MAS}$ NMR spectra with an $8 \mathrm{msec}$ contact time, which is used to selectively enhance the excitation of $\mathrm{Si}$ atoms that are near ${ }^{1} \mathrm{H}$ atoms. Figure S5b clearly shows the enhancement of the feature located at -102 ppm during cross polarization, which confirms the assignment of this feature to $\mathrm{Si}(\mathrm{OH})(\mathrm{OSi})_{3}$ atoms. In short, the appearance of the -112 and $-115 \mathrm{ppm}$ features in Fig. S5a suggest that the $\mathrm{Nb}$ atoms are incorporated into the framework as there are two distinct type of Q4 Si atoms (i.e., $\left.\mathrm{Si}(\mathrm{OM})_{4}\right)$, and these features are similar to those observed in related framework-substituted *BEA (i.e., $\mathrm{Nb}-\beta$ [43], Ta- $\beta$ [45], and $\mathrm{Zr}-\beta$ [44]).

$\mathrm{Nb}$-atom incorporation was also characterized by attenuated total reflectance IR spectroscopy (ATR-IR, Bruker Alpha). $\mathrm{Nb}_{1.5}-\beta$ and $\mathrm{Si}-\beta$ samples $(\sim 10 \mathrm{mg})$ were pressed onto a diamond ATRIR internal reflection element and IR spectra were recorded (32 scans, $2 \mathrm{~cm}^{-1}$ resolution) at ambient conditions. Figure $\mathrm{S} 6 \mathrm{a}$ shows IR spectra for $\mathrm{Si}-\beta$ and $\mathrm{Nb}_{1.5}-\beta$ samples just after heating to $823 \mathrm{~K}$ for $6 \mathrm{~h}$ in flowing air $\left(100 \mathrm{~cm}^{3} \mathrm{~min}^{-1}\right.$, Praxair, Ultra-zero grade), both of which exhibit absorbance features centered at 1234,1075 , and $803 \mathrm{~cm}^{-1}$, which correspond to the $\mathrm{SiO}_{4}$ internal tetrahedral stretch, the $v_{\mathrm{as}}(\mathrm{Si}-\mathrm{O})$, and the $v_{\mathrm{s}}(\mathrm{Si}-\mathrm{O})$ features, respectively [46]. $\mathrm{Nb}_{1.5}-\beta$ also possesses an additional feature in the ATR-IR spectra that is centered at $950 \mathrm{~cm}^{-1}$ (Fig. S6c), which corresponds to $v(\mathrm{Si}-\mathrm{O}-\mathrm{Nb})[43,47]$. Additionally, extra-framework $\mathrm{Nb}$ atoms would result in a distinct absorbance feature at $\sim 835 \mathrm{~cm}^{-1}$ which is assigned to $v_{\mathrm{s}}(\mathrm{O}-\mathrm{Nb}-\mathrm{O})$ of oligomeric or polymeric niobia [48]. Figure $\mathrm{S} 6 \mathrm{~d}$ shows the difference spectra for $\mathrm{Nb}_{10.0}-\mathrm{SiO}_{2}$ with respect to $\mathrm{SiO}_{2}$, and possesses a distinct absorbance feature at $831 \mathrm{~cm}^{-1}$, which suggests that $\mathrm{Nb}_{10.0}-\mathrm{SiO}_{2}$ contained oligomeric or bulk-like clusters of niobia on the surface. Notably, the lack of an 
additional IR absorbance feature (Fig. S6c) near $835 \mathrm{~cm}^{-1}$ suggests that these Nb- $\beta$ samples do not contain oligomeric or bulk forms of $\mathrm{NbO}_{\mathrm{x}}$. These data, in conjunction with DRUV-vis and solid-state $\mathrm{NMR}$, strongly suggest that $\mathrm{Nb}$ atoms have been incorporated into the $* \mathrm{BEA}$ framework and that no extra-framework $\mathrm{Nb}^{\mathrm{V}}$ is formed after the post-synthetic modification of *BEA.

The presence of Lewis acid sites was characterized by the FTIR spectroscopy of deuterated acetonitrile $\left(\mathrm{CD}_{3} \mathrm{CN}\right.$, Cambridge Isotope Laboratories, $99.8 \% \mathrm{D}$ atom $)[49,50]$ coordinated to $\mathrm{Nb}_{1.5}-\beta$ and Si- $\beta$ using a custom-made transmission cell, the design of which was described previously [51]. The transmission cell was mounted within an FTIR spectrometer (Bruker, Tensor 37) equipped with a liquid- $\mathrm{N}_{2}$ cooled $\mathrm{HgCeTe}$ detector. Catalysts were pressed into selfsupporting wafers $(\sim 80 \mathrm{mg})$ and placed within the stainless-steel cell, which was equipped with $\mathrm{CaF}_{2}$ windows and connected to a gas manifold by gas-transfer lines that were heated to $423 \mathrm{~K}$ via electrical heating tape (Omega, FGH Series). The catalyst temperature was measured using a K-type thermocouple (Omega) located within the cell. Catalysts were heated to $423 \mathrm{~K}$ at $10 \mathrm{~K}$ $\min ^{-1}$ and held at $423 \mathrm{~K}$ for $1.5 \mathrm{~h}$ under flowing $\mathrm{He}\left(50 \mathrm{~cm}^{3} \mathrm{~min}^{-1}\right.$, Airgas, Ultra High Purity) to remove $\mathrm{H}_{2} \mathrm{O}$ and then allowed to cool to $298 \mathrm{~K}$. Liquid $\mathrm{CD}_{3} \mathrm{CN}\left(1 \mu \mathrm{L} \mathrm{min}{ }^{-1}\right)$ was fed via a syringe pump (Legato 100, KD Scientific) and vaporized inside the heated gas-transfer lines into a stream of flowing $\mathrm{He}\left(50 \mathrm{~cm}^{3} \mathrm{~min}^{-1}\right)$ to generate a mixture $\left(1.2 \mathrm{kPa} \mathrm{CD} \mathrm{CD}_{3} \mathrm{CN}, 100 \mathrm{kPa} \mathrm{He}\right)$. Each catalyst was then contacted with the $\mathrm{CD}_{3} \mathrm{CN} / \mathrm{He}$ stream until reaching the saturation coverage of $\mathrm{CD}_{3} \mathrm{CN}$ (determined by constant absorbance intensities in FTIR spectra, $\sim 15 \mathrm{~min}$ ) at which point the $\mathrm{CD}_{3} \mathrm{CN}$ flow was stopped. . The sample was then heated at $10 \mathrm{~K} \mathrm{~min}^{-1}$ to increasing temperatures in $20 \mathrm{~K}$ increments to a maximum temperature of $423 \mathrm{~K}$, and steadystate FTIR spectra (128 scans, $1 \mathrm{~cm}^{-1}$ resolution) were acquired continuously. 

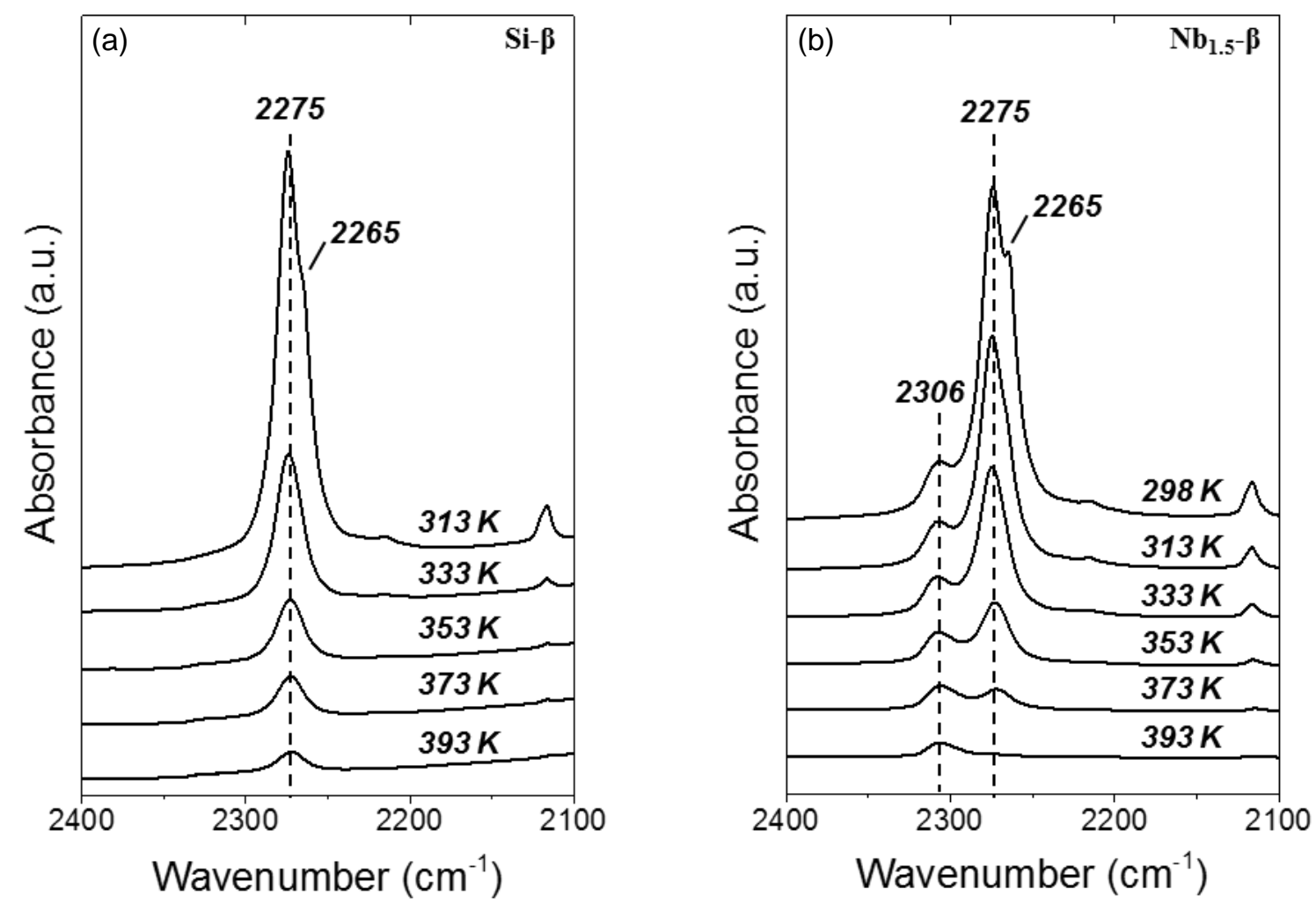

Figure 1. Infrared spectra of adsorbed $\mathrm{CD}_{3} \mathrm{CN}$ on the (a) $\mathrm{Si}-\beta$ and (b) $\mathrm{Nb}_{1.5}-\beta$ samples at the indicated temperatures within a steam of flowing $\mathrm{He}(101 \mathrm{kPa})$. Prior to the acquisition of these spectra, the samples were saturated with $\mathrm{CD}_{3} \mathrm{CN}$ at $298 \mathrm{~K}\left(1.2 \mathrm{kPa} \mathrm{CD}{ }_{3} \mathrm{CN}, 100 \mathrm{kPa} \mathrm{He}, 50 \mathrm{~cm}^{3}\right.$ $\min ^{-1}$ ), after which $\mathrm{CD}_{3} \mathrm{CN}$ flow was stopped.

Figure 1 shows representative FTIR spectra for $\mathrm{CD}_{3} \mathrm{CN}$ adsorbed on $\mathrm{Si}-\beta$ (Fig. 1a) and $\mathrm{Nb}_{1.5^{-}}$ $\beta$ (Fig. 1b). Absorption features between $2260-2340 \mathrm{~cm}^{-1}$ correspond to the $v(\mathrm{C} \equiv \mathrm{N})$ mode, while the band near $2115 \mathrm{~cm}^{-1}$ arises from the $\delta_{\mathrm{s}}\left(\mathrm{CD}_{3}\right)$ mode [50]. The absorbance peak located at $2275 \mathrm{~cm}^{-1}$ (Fig. 1a) is associated with $\mathrm{CD}_{3} \mathrm{CN}$ hydrogen bonded to silanol groups located within the zeolite, while the shoulder located at $2265 \mathrm{~cm}^{-1}$ is attributed to physisorbed $\mathrm{CD}_{3} \mathrm{CN}$, which weakly interacts with the pore walls [50]. As the temperature of the Si- $\beta$ sample increases, hydrogen-bonded $\mathrm{CD}_{3} \mathrm{CN}$ species $\left(2275 \mathrm{~cm}^{-1}\right)$ persist on the surface, while the physisorbed 
$\mathrm{CD}_{3} \mathrm{CN}\left(2265 \mathrm{~cm}^{-1}\right)$ desorb. Spectra of $\mathrm{CD}_{3} \mathrm{CN}$ on $\mathrm{Nb}_{1.5}-\beta$ (Fig. 1b, $298 \mathrm{~K}$ ) largely resemble those of Si- $\beta$ but possess an additional absorption feature at $2306 \mathrm{~cm}^{-1}$ that can be attributed to Lewis acid sites associated with adsorption on $\mathrm{Nb}$ atoms, similar to $\mathrm{CD}_{3} \mathrm{CN}$ features on $\mathrm{Sn}-\beta$ [49]. Yet these spectra on $\mathrm{Nb}_{1.5}-\beta$ show only a single new feature, in contrast to FTIR spectra of $\mathrm{CD}_{3} \mathrm{CN}$ on Sn- $\beta$, which show features at both 2308 and $2316 \mathrm{~cm}^{-1}$ and reflect the presence of both open and closed Lewis acid sites [49]. Consequently, we conclude that $\mathrm{Nb}_{1.5}-\beta$ possesses predominantly one type of Lewis acid site, because additional types of Lewis acid sites would result in multiple absorbance peaks in the $2300 \mathrm{~cm}^{-1}$ region [52]. These results (Fig. 1) taken together with NMR spectra (Fig. S4 and S5) strongly suggest that the Lewis acid sites are Nbatoms tetra-coordinated within the zeolite framework [52].

The UV-vis (Fig. S2 and S3), solid-state NMR (Fig. S4 and S5), and ATR-IR (Fig. S6) data show that $\mathrm{Nb}$ atoms are incorporated into the *BEA framework and do not exist as extraframework bulk or oligomeric niobia. Additionally, the IR spectra of adsorbed $\mathrm{CD}_{3} \mathrm{CN}$ (Fig. 1b) show a single absorbance feature associated with Lewis acidic sites. It is possible that multiple types of $\mathrm{Nb}$ sites exist in $\mathrm{Nb}-\beta$, that have similar IR absorption features for adsorbed $\mathrm{CD}_{3} \mathrm{CN}$ and also possess similar heats of adsorption that preclude their detection; however, this seems to be unlikely due to the significant shift in wavenumbers (2308 and $2316 \mathrm{~cm}^{-1}$ ) and different heats of adsorption seen in Sn- $\beta$ for open and closed sites [49]. These Lewis acid sites are most likely to be $\mathrm{Nb}$ atoms tetra-coordinated to the framework of $\beta$ and to possess a single pendant $-\mathrm{OH}$ (i.e., $\left.\mathrm{Nb}(\mathrm{OSi})_{4}(\mathrm{OH})\right)$ based on the characterization here, together with previous results that combined experiments (i.e., solid-state NMR, powder XRD, UV-vis, XPS, and IR spectroscopy) and theory (i.e., ab initio DFT calculations) to show that the most energetically stable form of $\mathrm{Nb}$ in $\mathrm{Nb}-\beta$ is the $\mathrm{Nb}(\mathrm{OSi})_{4}(\mathrm{OH})$ unit $[26,43]$. 
X-ray photoelectron spectroscopy (XPS) measurements were used to measure the oxidation state of $\mathrm{Nb}$ atoms in $\mathrm{Nb}_{5.0^{-}} \beta$ and $\mathrm{H}_{2} \mathrm{O}_{2}$-activated $\mathrm{Nb}_{5.0^{-}} \beta$ (Section 2.4) and were performed on a Kratos AXIS Ultra spectrometer with a monochromatic Al-Ka $(1486.6 \mathrm{eV}) \mathrm{X}$-ray source. Highresolution spectra were collected with $40 \mathrm{eV}$ pass energy, and the binding-energy scales were referenced with respect to the aliphatic $\mathrm{C}$ 1s absorbance feature at $284.8 \mathrm{eV}$. Peak fittings were done in CasaXPS@ via the method of Shirley.

\subsection{Epoxide Formation and $\mathrm{H}_{2} \mathrm{O}_{2}$ Consumption Rate Measurements}

Reaction rates for epoxidation were measured using a batch reactor $\left(100 \mathrm{~cm}^{3}\right.$, three-neck round bottom flask) equipped with a reflux condenser to minimize evaporative losses. For typical reaction conditions, the reactor was filled with a solvent mixture of $\sim 30 \mathrm{~cm}^{3}$ acetonitrile $\left(\mathrm{CH}_{3} \mathrm{CN}\right.$, Macron Chemicals, >99.8\%) and $30 \mu \mathrm{L}$ benzene (Sigma-Aldrich, thiophene free, $>99 \%$ ) as an internal standard. The reagents, $\mathrm{C}_{6} \mathrm{H}_{10}$ (Sigma-Aldrich, >99\%) or cis-stilbene (Sigma-Aldrich, >96\%) and $\mathrm{H}_{2} \mathrm{O}_{2}$ (Fischer Chemicals, 30 wt. \% in $\mathrm{H}_{2} \mathrm{O}$ ), were added and the reaction mixture was heated to the desired temperature $(303-333 \mathrm{~K})$ while stirring at $450 \mathrm{rpm}$. The epoxidation of $\mathrm{C}_{6} \mathrm{H}_{10}$ was initiated by introducing $\sim 30 \mathrm{mg}$ of the $\mathrm{Nb}-\beta$ catalyst. Small aliquots $(\sim 300 \mu \mathrm{L})$ were extracted through a $0.22 \mu \mathrm{m}$ filter (GS-Tek, PVDF filter) to remove suspended catalyst, and thus quench $\mathrm{C}_{6} \mathrm{H}_{10}$ epoxidation and $\mathrm{H}_{2} \mathrm{O}_{2}$ decomposition. All reactants and solvents used were miscible under the conditions tested in this study. The concentrations of $\mathrm{C}_{6} \mathrm{H}_{10} \mathrm{O}$ and other potential reaction products (e.g., cyclohexane diol and cyclohexanol) were determined as a function of time with a gas chromatograph (HP-5890 Series A) equipped with a non-polar dimethylpolysiloxane capillary column (Agilent, HP-1, $30 \mathrm{~m}$ length, $1.05 \mu \mathrm{m}$ ) and a flame ionization detector. All species were identified and response factors were calculated using calibrated mixtures of known standards. The change in the concentration of $\mathrm{H}_{2} \mathrm{O}_{2}$ was 
determined by colorimetric titrations using a solution of $\mathrm{Cu}$-based indicator $(12 \mathrm{mM}$ neocuproine (Sigma-Aldrich, >98\%); 8.3 mM CuSO 4 (Fisher Chemicals, >98.6\%); 25\% v/v ethanol (Decon Laboratories Inc., 100\%)) [53, 54]. The concentrations of $\mathrm{H}_{2} \mathrm{O}_{2}$ in each aliquot was determined from the absorbance at $454 \mathrm{~nm}$, measured using a visible-light spectrophotometer (Spectronic, 20 Genesys), and by comparison to calibrated standards. In all reported data, the selectivity towards $\mathrm{C}_{6} \mathrm{H}_{10} \mathrm{O}$ formation was $>99 \%$ (e.g., no common byproducts were detected, such as cyclohexanol or cyclohexane diol) upon reaction of $\mathrm{C}_{6} \mathrm{H}_{10}$ with $\mathrm{H}_{2} \mathrm{O}_{2}$ over $\mathrm{Nb}-\beta$. The carbon balance closed to within 98\% for all reactions reported, which shows all significant reaction products were detected. The calculated uncertainties for all turnover rate measurements are less than $7 \%$, as determined by comparison of repeated measurements.
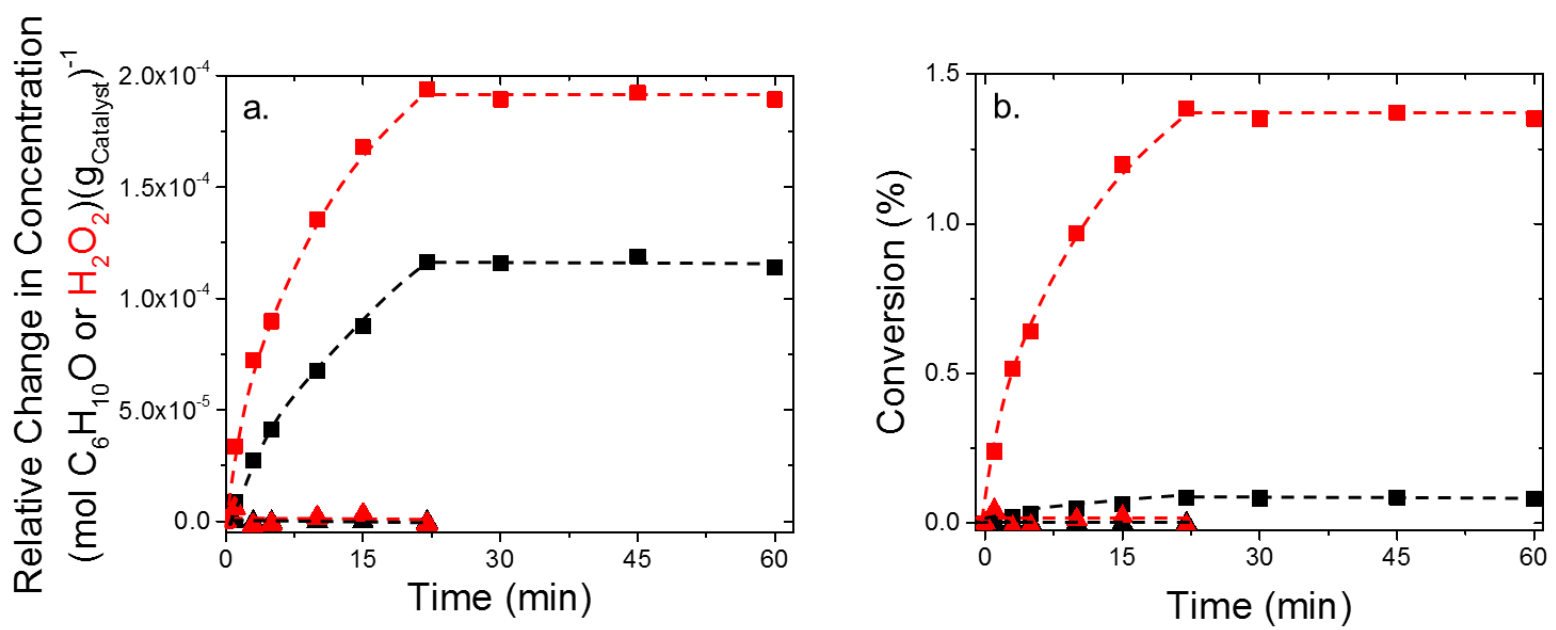

Figure 2. Concentration profiles for the formation of $\mathrm{C}_{6} \mathrm{H}_{10} \mathrm{O}$ (black) and for the consumption of $\mathrm{H}_{2} \mathrm{O}_{2}$ (red) as a function of time expressed as (a) Relative Change in Concentration (given in mol $\left(\mathrm{g}_{\mathrm{cat}}\right)^{-1}$ ) for direct comparison between catalysts, as there is no $\mathrm{Nb}$ present in $\mathrm{Si}-\beta$, and (b) conversion of $\mathrm{C}_{6} \mathrm{H}_{10}\left(\right.$ taken as $\left(\right.$ mol $\left.\left._{C_{6} H_{10} 0}\right)\left(\text { mol }_{C_{6} H_{10}, \text { intitial }}\right)^{-1}\right)$ or $\mathrm{H}_{2} \mathrm{O}_{2}\left(10 \mathrm{mM} \mathrm{C}_{6} \mathrm{H}_{10}, 1 \mathrm{mM} \mathrm{H}_{2} \mathrm{O}_{2}, \mathrm{Nb}_{1.5}\right.$ $\beta(\boldsymbol{\bullet})$ or $\mathrm{Si}-\beta(\boldsymbol{\Delta})$ in $\mathrm{CH}_{3} \mathrm{CN}, 313 \mathrm{~K}$ ) with hot filtration at 22 minutes. Lines are intended to guide the eye.

Control experiments were performed using Si- $\beta$ and $\mathrm{Nb}_{1.5}-\beta$ to demonstrate that the metal centers contained within the zeolite were responsible for $\mathrm{C}_{6} \mathrm{H}_{10}$ epoxidation and $\mathrm{H}_{2} \mathrm{O}_{2}$ 
consumption. Figure 2 shows that turnover numbers (TON) for $\mathrm{C}_{6} \mathrm{H}_{10}$ epoxidation and $\mathrm{H}_{2} \mathrm{O}_{2}$ consumption are undetectable on $\mathrm{Si}-\beta$ but increase with time on $\mathrm{Nb}_{1.5}-\beta$, which shows that the $\mathrm{Nb}$ atoms in the framework catalyze epoxidation and $\mathrm{H}_{2} \mathrm{O}_{2}$ conversion. The values of the TON become constant (i.e., turnover rates are zero) after hot filtration, suggesting that $\mathrm{Nb}$-atoms do not leach into solution and homogeneously catalyze epoxidation. Additionally, ICP-OES analyses of the reaction solution (after $1 \mathrm{~h}$ of reaction) and of the spent $\mathrm{Nb}_{1.5}-\beta$ show no discernible changes in the $\mathrm{Nb}$ content of either the liquid phase or the solid catalyst. The ICPOES analysis performed has an experimental error of \pm 0.01 wt. \%, which correlates to a sensitivity of $<1 \%$ of the total $\mathrm{Nb}$ content of the catalyst. Turnover rates reported in all subsequent sections were obtained in the linear region (i.e., first $5 \mathrm{~min}$ ) of olefin epoxidation at differential conversion (i.e., $<5 \%$ conversion of $\mathrm{C}_{6} \mathrm{H}_{10}$ and $\mathrm{H}_{2} \mathrm{O}_{2}$ ).

Reported rates of $\mathrm{C}_{6} \mathrm{H}_{10}$ epoxidation and $\mathrm{H}_{2} \mathrm{O}_{2}$ consumption were measured in the absence of mass-transfer limitations. To ensure that the Madon-Boudart criterion [55] was satisfied, reactions were performed with $\mathrm{Nb}-\beta$ catalysts with different metal loadings $(0.15-1.5$ wt. $\%$ $\mathrm{Nb}$ ) at constant $\mathrm{H}_{2} \mathrm{O}_{2}$ concentrations over a range of $\mathrm{C}_{6} \mathrm{H}_{10}$ concentrations (Section S2, Fig. S8). Epoxidation turnover rates did not depend on the $\mathrm{Nb}$ content over this range of weight loadings, which shows that intra-pellet mass-transfer limitations were insignificant. Reported turnover rates and kinetic analyses are taken from experiments using $\mathrm{Nb}_{1.5}-\beta$.

\subsection{Activation of $\mathrm{Nb}-\beta$ with $\mathrm{H}_{2} \mathrm{O}_{2}$ for XPS Analysis}

$\mathrm{Nb}_{5.0}-\beta\left(200 \mathrm{mg}\right.$ ) was combined with a mixture of $2.5 \mathrm{~cm}^{3} \mathrm{CH}_{3} \mathrm{CN}$ and $2.5 \mathrm{~cm}^{3} \mathrm{H}_{2} \mathrm{O}_{2}$ (30 wt. $\%$ in $\mathrm{H}_{2} \mathrm{O}$ ) to produce $\mathrm{H}_{2} \mathrm{O}_{2}$-activated $\mathrm{Nb}_{5.0}-\beta$ for XPS analysis of the $\mathrm{Nb}$ oxidation states. The $\mathrm{Nb}_{5.0}-\beta$ changed from bleached white to pale yellow in color upon addition of the $\mathrm{H}_{2} \mathrm{O}_{2}-\mathrm{CH}_{3} \mathrm{CN}$ mixture. This slurry was then heated to $333 \mathrm{~K}$ for $1 \mathrm{~h}$ with the intent of reacting all of the $\mathrm{Nb}$ 
active sites with $\mathrm{H}_{2} \mathrm{O}_{2}$ in solution. The slurry was then dried under dynamic vacuum (5.3 kPa) at $333 \mathrm{~K}$ for 30 minutes followed by static vacuum $(0.02 \mathrm{kPa})$ for 12 hours, which gave the final $\mathrm{H}_{2} \mathrm{O}_{2}$-activated $\mathrm{Nb}_{5.0}-\beta$ material (light yellow solid).

\subsection{In Situ UV-Vis and IR Spectroscopy}

In situ UV-vis spectroscopy was used to measure the reactivity of the different intermediates for epoxidation on $\mathrm{Nb}-\beta . \mathrm{Nb}_{0.3}-\beta$ samples were pressed into $7 \mathrm{~mm}$ diameter self-supporting pellets $(\sim 5 \mathrm{mg})$ and loaded into a custom-built UV-vis liquid flow cell. Reactant and solvent solutions were introduced using a high-performance liquid chromatography (HPLC) pump (Waters, 515), and UV-vis spectra were collected using a 45-degree reflection probe (Avantes, solarization-resistant fibers) attached to an AvaFast fiber-optic spectrometer (Avantes 2048) with a compact deuterium-halogen light source (Avantes, $200-1700 \mathrm{~nm}$ ). The $\mathrm{Nb}_{0.3}-\beta$ samples were activated by flowing $\left(1 \mathrm{~cm}^{3} \mathrm{~min}^{-1}\right)$ a solution of $\mathrm{H}_{2} \mathrm{O}_{2}$ in $\mathrm{CH}_{3} \mathrm{CN}\left(0.1 \mathrm{M} \mathrm{H}_{2} \mathrm{O}_{2}, 0.4 \mathrm{M} \mathrm{H}_{2} \mathrm{O}\right)$ over the pellet at $313 \mathrm{~K}$ until the absorbance features at $\sim 320 \mathrm{~nm}$ were unchanging $(\sim 15 \mathrm{~min})$. A H${ }_{2} \mathrm{O}_{2}$-free solution of $\mathrm{CH}_{3} \mathrm{CN}\left(0.4 \mathrm{M} \mathrm{H}_{2} \mathrm{O}\right)$ then flowed through the reactor $\left(1 \mathrm{~cm}^{3} \mathrm{~min}^{-1}\right)$ to remove all liquid-phase and weakly adsorbed $\mathrm{H}_{2} \mathrm{O}_{2}$ from the system at $313 \mathrm{~K}$. This treatment did not attenuate the UV-vis absorbance features, which shows that the surface species on $\mathrm{H}_{2} \mathrm{O}_{2}$ activated $\mathrm{Nb}_{0.3}-\beta$ were stable at $313 \mathrm{~K}$ under pure $\mathrm{CH}_{3} \mathrm{CN}$. The reactivity of the surface intermediates on $\mathrm{Nb}_{0.3}-\beta$ was measured by continuously acquiring UV-vis spectra $(600 \mathrm{msec}$ integration time, co-adding 100 scans per spectrum) while flowing a solution of $\mathrm{C}_{6} \mathrm{H}_{10}$ in $\mathrm{CH}_{3} \mathrm{CN}$

(0.1 $\mathrm{M} \mathrm{C}_{6} \mathrm{H}_{10}, 0.4 \mathrm{M} \mathrm{H}_{2} \mathrm{O}$ ), similar to that used for rate measurements in the batch reactor. Reference spectra for all experiments were obtained using a $\mathrm{Nb}_{0.3}-\beta$ pellet within a flowing $\mathrm{CH}_{3} \mathrm{CN}$ solution $\left(0.4 \mathrm{M} \mathrm{H}_{2} \mathrm{O}\right)$ at $313 \mathrm{~K}$. Peak smoothing, background subtraction, and spectral deconvolution were performed in OriginPro® (Section S3.1 for example spectra). 
In situ attenuated total reflectance infrared (ATR-IR) spectroscopy was used to characterize the vibrational structure and chemical stability of the intermediates formed upon exposing $\mathrm{Nb}-\beta$ to $\mathrm{H}_{2} \mathrm{O}_{2}$. Untreated $\mathrm{Nb}_{1.5}-\beta$ was deposited onto a $\mathrm{ZnSe}$ cylindrical internal reflection element (IRE, International Crystal Labs) by dip coating. Briefly, $100 \mathrm{mg}$ of $\mathrm{Nb}_{1.5^{-}}-\beta$ were suspended in $\sim 10 \mathrm{~cm}^{3}$ of $\mathrm{CH}_{3} \mathrm{OH}$ (Macron Chemicals, anhydrous) and the IRE was dipped into the suspension and subsequently dried at ambient temperature to retain the powdered catalyst on the IRE. A series of 10 cycles were typically used to accumulate a thin layer of $\mathrm{Nb}_{1.5}-\beta$. The catalyst-coated IRE was then loaded into a customized ATR flow cell (Axiom TNL-120) equipped with two liquid inlets and one outlet with a cell volume of $40 \mu \mathrm{L}$. The ATR cell was mounted within the sample compartment of a FTIR spectrometer (Bruker Vertex 70, RapidScan) and liquid streams were introduced at controlled flowrates using two high-pressure piston pumps (SSI Series 1), which were controlled using LabView ${ }^{\mathrm{TM}}$. Background scans were obtained at steady-state under pure flowing DI $\mathrm{H}_{2} \mathrm{O}$ at $333 \mathrm{~K}$ after loading the ATR cell. Transient FTIR spectra showing changes upon introducing $\mathrm{H}_{2} \mathrm{O}_{2}$ were obtained while flowing aqueous $\mathrm{H}_{2} \mathrm{O}_{2}\left(0.03 \mathrm{M} \mathrm{H}_{2} \mathrm{O}_{2}\right.$ in DI $\mathrm{H}_{2} \mathrm{O}, 0.5 \mathrm{~cm}^{3} \mathrm{~min}^{-1}$ ) over the $\mathrm{Nb}_{1.5}-\beta$ coated IRE for $2.5 \mathrm{~h}$ at $333 \mathrm{~K}$. Subsequently, a stream of pure DI $\mathrm{H}_{2} \mathrm{O}$ was pumped through the cell at $0.5 \mathrm{~cm}^{3} \mathrm{~min}^{-1}$ for $1 \mathrm{~h}$. Reported FTIR spectra for these experiments are the average of 1000 scans taken at a resolution of $4 \mathrm{~cm}^{-1}$ and were acquired every 66 seconds. Deconvolution of steady-state FTIR spectra were performed in OriginPro $^{\circledR}$ by fixing the centers of the known framework vibrations attributed to the BEA framework of $\mathrm{Nb}_{1.5}-\beta\left(950 \mathrm{~cm}^{-1}, 1090 \mathrm{~cm}^{-1}\right)[43,46,47,56,57]$ and fitting the residual absorbance features with Gaussian functions.

Modulation excitation spectroscopy (MES) is a powerful technique, in which a periodic stimulation is applied to the system while acquiring spectra as a function of time. The time 
domain response is then converted to a phase domain response, and the spectral changes that occur at the frequency of the applied stimulation are extracted using a phase sensitive detection (PSD) method described by the following equation:

$$
A_{k}\left(\varphi_{k}^{P S D}\right)=\frac{2}{T} \int_{0}^{T} A(t) \sin \left(k \omega t+\varphi_{k}^{P S D}\right) d t
$$

where $\mathrm{A}(\mathrm{t})$ and $\mathrm{A}_{\mathrm{k}}\left(\varphi_{\mathrm{k}}^{\mathrm{PSD}}\right)$ are time- and phase- domain response of the active species respectively, $\mathrm{T}$ is the length of a time period, $\omega$ is the demodulation index and $\varphi_{\mathrm{k}}^{\mathrm{PSD}}$ is the user defined phase demodulation angle. The application of the MES-PSD technique to FTIR spectra of intermediates on catalytic surfaces greatly increases the signal to noise ratio, suppresses the spectral contributions of static (i.e., spectator) species, and reveals high quality spectra containing contributions only of intermediates that change with respect to our applied stimulus (i.e., changing reactant concentrations) [58].

MES-PSD was used with ATR-IR to confirm that the predominant surface intermediates that form upon exposing $\mathrm{Nb}_{1.5}-\beta$ to aqueous $\mathrm{H}_{2} \mathrm{O}_{2}$ solutions (vide supra) are, in fact, active species for the epoxidation of olefins. MES-PSD experiments were performed by sinusoidally modulating the flowrates of two liquid streams $\left(0.065 \mathrm{M} \mathrm{H}_{2} \mathrm{O}_{2}\right.$ in $\mathrm{CH}_{3} \mathrm{CN}$, and $0.1 \mathrm{M} \mathrm{C}_{6} \mathrm{H}_{10}$ in $\left.\mathrm{CH}_{3} \mathrm{CN}\right)$ from 0 to $0.5 \mathrm{~cm}^{3} \mathrm{~min}^{-1}$ with a period of $0.5 \mathrm{~h}$ (which approximately corresponds to the turnover rate for epoxidation at these conditions), while maintaining a total flowrate of $0.5 \mathrm{~cm}^{3} \mathrm{~min}^{-1}$. Spectra (128 scans, $4 \mathrm{~cm}^{-1}$ ) were acquired every $8.5 \mathrm{sec}$ over $3 \mathrm{~h}$. Flowrates were sinusoidally modulated and controlled on the two piston pumps through use of a LabView program that changes the set point of the pump in a step-wise manner every $0.5 \mathrm{~s}$ to approximate a sine wave with the desired frequency. Verification of sinusoidal reactant modulation was done by monitoring and absorbance feature at $1630 \mathrm{~cm}^{-1}$, that is assigned to the $v_{2}$ bending mode of $\mathrm{H}_{2} \mathrm{O}$ [59], as a 
function of phase angle (Fig. S10) because $\mathrm{H}_{2} \mathrm{O}$ was only present in the $\mathrm{H}_{2} \mathrm{O}_{2}$-containing stream. The recorded time domain spectra were resampled to a single period, and subsequently the spectra of the active species were extracted by PSD using equation 1. Details of the analysis method are described in Section S4.1.

\subsection{Spectroscopic Evidence for an Irreversibly Formed $\mathrm{Nb}-\left(\mathrm{O}_{2}\right)^{-}$Active Intermediate}

Metal-bound oxygen intermediates (i.e., superoxide $\left(\mathrm{M}-\left(\mathrm{O}_{2}\right)^{-}\right)$, peroxide $\left(\mathrm{M}-\left(\mathrm{O}_{2}\right)^{2-}\right)$, and hydroperoxide (M-OOH)), have been implicated in the epoxidation of olefins (e.g., propylene, cyclohexene, allylic alcohol) on metal-oxide catalysts (e.g., Ta-SBA-15 [21], TS-1 [60, 61], and peroxoniobate ionic liquids [62]). The primary distinction between superoxide and peroxide species is the charge of the $-\mathrm{O}_{2}$ moiety bound to the metal (i.e., superoxide $\left(-\mathrm{O}_{2}{ }^{-}\right)$and peroxide (-

$\left.\mathrm{O}_{2}\right)^{2-}$ ), and is, therefore, reflected in the oxidation state of the metal center (e.g., $\mathrm{Ti}^{\mathrm{III}}-\left(\mathrm{O}_{2}\right)^{-}$vs. $\mathrm{Ti}^{\mathrm{IV}}-\left(\mathrm{O}_{2}\right)^{2-}$; or $\mathrm{Nb}^{\mathrm{IV}}-\left(\mathrm{O}_{2}\right)^{-}$vs. $\left.\mathrm{Nb}^{\mathrm{V}}-\left(\mathrm{O}_{2}\right)^{2-}\right)[63,64]$. Zecchina [65] and Frei [60] used combinations of IR, Raman, and UV-vis spectroscopy to show that reactive $\mathrm{Ti}^{\mathrm{IV}}-\left(\mathrm{O}_{2}\right)^{2-}$ and/or $\mathrm{Ti}^{\mathrm{iV}}-\mathrm{OOH}$ species form by activation of $\mathrm{H}_{2} \mathrm{O}_{2}$ on TS-1. However, Ratnasamy et al. used in situ electron paramagnetic resonance (EPR) spectroscopy and determined that a paramagnetic Ti-superoxo ( $\left.\mathrm{Ti}^{\mathrm{III}}-\left(\mathrm{O}_{2}\right)^{-}\right)$species is created on TS-1 upon activation of $\mathrm{H}_{2} \mathrm{O}_{2}$ and is active and selective for the epoxidation of allylic alcohol [66], and the exact identity of the reactive intermediate on TS-1 (specifically the $\mathrm{Ti}^{\mathrm{IV}}-\mathrm{OOH}$ or $\left.\mathrm{Ti}^{\mathrm{III}}-\left(\mathrm{O}_{2}\right)^{-}\right)[63,64,67,68]$ is still debated. Similar types of hydroperoxo, peroxo, and superoxo species (i.e., $\mathrm{Nb}^{\mathrm{V}}-\mathrm{OOH}, \mathrm{Nb}^{\mathrm{V}}-\left(\mathrm{O}_{2}\right)^{2-}$, or $\left.\mathrm{Nb}^{\mathrm{IV}}-\left(\mathrm{O}_{2}\right)^{-}\right)$likely form when $\mathrm{H}_{2} \mathrm{O}_{2}$ reacts with $\mathrm{Nb}-\beta$, and the vibrational structure, electronic transitions, and oxidation states, of the reactive complexes may be determined with the combination of FTIR, UV-vis, and x-ray photoelectron spectroscopy. 

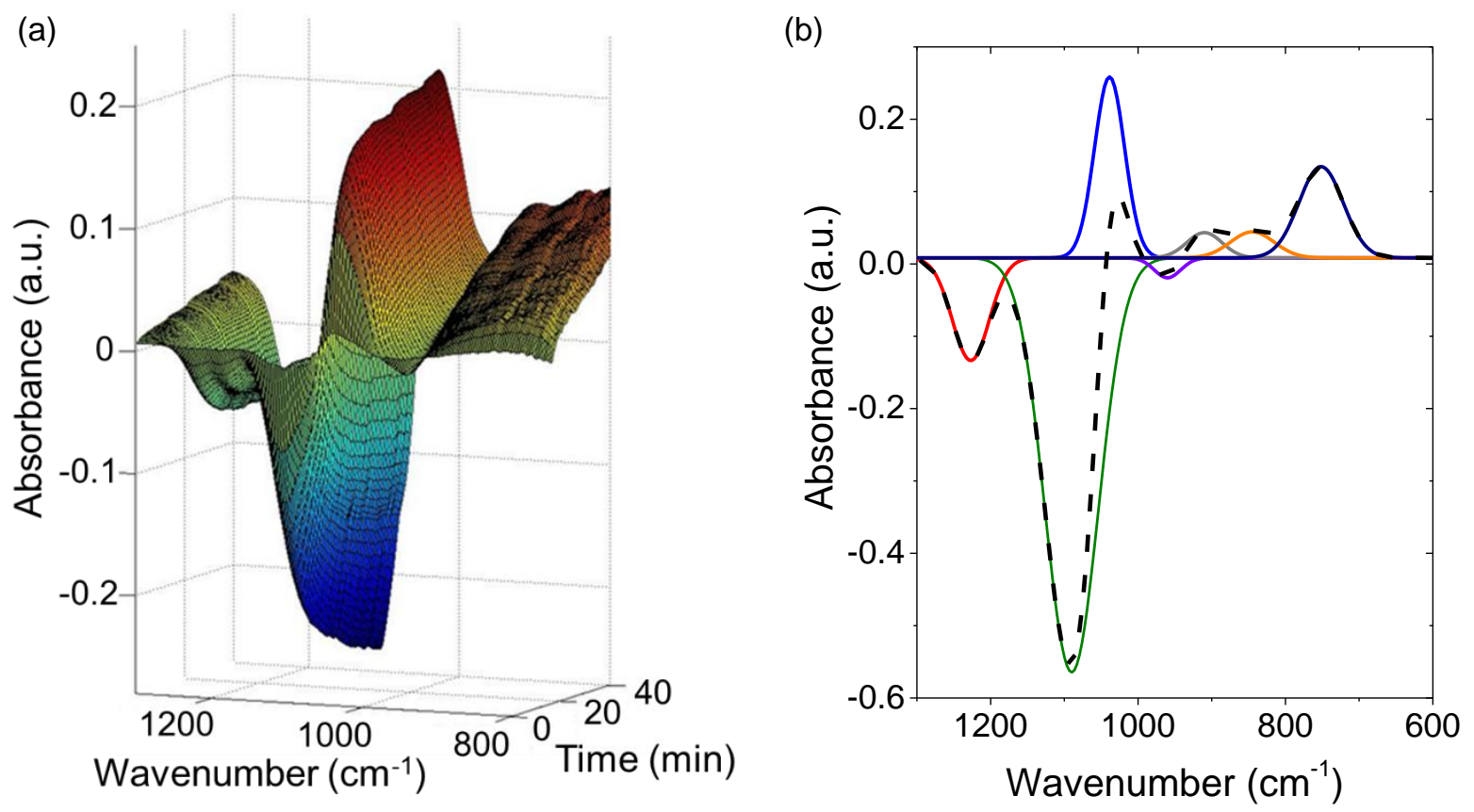

Figure 3. In situ FTIR spectra obtained upon exposing $\mathrm{Nb}_{1.5}-\beta$ to $\mathrm{H}_{2} \mathrm{O}_{2}\left(0.03 \mathrm{M} \mathrm{H}_{2} \mathrm{O}_{2}\right.$ in $\mathrm{CH}_{3} \mathrm{CN}$, $0.5 \mathrm{~cm}^{3} \mathrm{~min}^{-1}, 333 \mathrm{~K}$ ) showing, a) changes in the infrared spectra of $\mathrm{Nb}-\beta$ upon first contact with flowing $\mathrm{H}_{2} \mathrm{O}_{2}$, and b) deconvoluted FTIR spectrum obtained at steady-state after flowing $\mathrm{H}_{2} \mathrm{O}_{2}$ for $2 \mathrm{hr}$. Vibrational frequencies and peak assignments are given in Table 2. 
Table 2. Observed Vibrational Frequencies and Mode Assignments for the Deconvoluted FTIR Spectrum in Figure $3 b$.

\begin{tabular}{|c|c|c|}
\hline Vibrational Frequency $\left(\mathrm{cm}^{-1}\right)$ & Vibrational Assignment & Parent Species \\
\hline 750 & Libration [59] & Water \\
\hline 845 & $v(\mathrm{O}-\mathrm{O})[67,69]$ & $\begin{array}{l}\mathrm{Nb}^{\mathrm{V}}-\mathrm{OOH} / \\
\mathrm{Nb}^{\mathrm{V}}-\left(\mathrm{O}_{2}\right)^{2-}\end{array}$ \\
\hline 915 & $\begin{array}{l}\text { Internal tetrahedral - } \\
\text { asymmetric stretch [46] }\end{array}$ & *BEA Framework \\
\hline 950 & $v(\mathrm{Si}-\mathrm{O}-\mathrm{Nb})[43,47]$ & $\mathrm{Nb}-\beta$ \\
\hline 1040 & $v(\mathrm{O}-\mathrm{O})[69-71]$ & $\mathrm{Nb}^{\mathrm{IV}}-\left(\mathrm{O}_{2}\right)^{-}$ \\
\hline 1090 & $\begin{array}{c}\text { Internal tetrahedral - asymmetric } \\
\text { stretch }[46,47,56,57]\end{array}$ & *BEA Framework \\
\hline 1230 & $\begin{array}{l}\text { Internal tetrahedral - asymmetric } \\
\text { stretch }[46,47,56,57]\end{array}$ & *BEA Framework \\
\hline
\end{tabular}

Figure 3 shows FTIR spectra obtained upon exposing $\mathrm{Nb}_{1.5}-\beta$ to a flowing solution of $\mathrm{H}_{2} \mathrm{O}_{2}$ $\left(0.03 \mathrm{M} \mathrm{H}_{2} \mathrm{O}_{2}\right.$ in $\left.\mathrm{CH}_{3} \mathrm{CN}, 0.5 \mathrm{~cm}^{3} \min ^{-1}, 333 \mathrm{~K}\right)$. Figure 3a shows that several new absorption features appear (i.e., $1040 \mathrm{~cm}^{-1}, 845 \mathrm{~cm}^{-1}$, and $915 \mathrm{~cm}^{-1}$ ), while existing absorption features attenuate (i.e., $950 \mathrm{~cm}^{-1}, 1090 \mathrm{~cm}^{-1}$, and $1230 \mathrm{~cm}^{-1}$ ) when $\mathrm{Nb}_{1.5}-\beta$ contacts $\mathrm{H}_{2} \mathrm{O}_{2}$, and Figure $3 \mathrm{~b}$ shows a representative steady-state FTIR spectrum acquired $\sim 2 \mathrm{~h}$ after initiating the flow of $\mathrm{H}_{2} \mathrm{O}_{2}$. The steady-state spectrum (Fig. 3b) is comprised of seven individual components, which are listed in Table 2 along with the corresponding vibrational assignments. The negative absorbance features at 1090 and $1230 \mathrm{~cm}^{-1}$ and the positive feature at $915 \mathrm{~cm}^{-1}$ are attributed to the quenching and stimulation, respectively, of internal framework tetrahedral Si-O vibrational modes in the *BEA framework $[46,47,56,57]$. The absorbance feature at $750 \mathrm{~cm}^{-1}$ corresponds to the libration band of liquid-phase $\mathrm{H}_{2} \mathrm{O}$ [59]. The absorbance peak observed at $845 \mathrm{~cm}^{-1}$ closely matches previously reported features at $837 \mathrm{~cm}^{-1}\left(\mathrm{Ti}^{\mathrm{IV}}-\mathrm{OOH} / \mathrm{Ti}^{\mathrm{IV}}-\left(\mathrm{O}_{2}\right)^{2-}\right.$ moieties on TS-1 [60, 
68]) and in the range of $850-888 \mathrm{~cm}^{-1}\left(\mathrm{Nb}^{\mathrm{V}}-\mathrm{OOH}\right.$ and $\left.\mathrm{Nb}^{\mathrm{V}}-\left(\mathrm{O}_{2}\right)^{2-}\right)$ species on niobate ionic liquids [62] and bulk niobia [69], respectively. Consequently, we attribute this feature to $\mathrm{Nb}^{\mathrm{V}}$ $\mathrm{OOH} / \mathrm{Nb}^{\mathrm{V}}-\left(\mathrm{O}_{2}\right)^{2-}$ intermediate(s). The feature at $1040 \mathrm{~cm}^{-1}$ resembles that previously attributed to superoxide $\left(\mathrm{O}_{2}^{-}\right)$moieties bound to Nb-centers of bulk $\mathrm{Nb}_{2} \mathrm{O}_{5}$ [69]. The formation of $\mathrm{Nb}^{\mathrm{V}}-\left(\mathrm{O}_{2}\right)^{2-}$ and $\mathrm{Nb}^{\mathrm{IV}}-\left(\mathrm{O}_{2}\right)^{-}$species must occur concomitantly with the cleavage of an Nb-O-Si linkage shown by the formation of the negative feature at $950 \mathrm{~cm}^{-1}$ [43]. Additionally, Corma [70] and Wan [71] observed spectral features with similar wavenumber $\left(900-1150 \mathrm{~cm}^{-1}\right)$ upon activating $\mathrm{O}_{2}$ over $\mathrm{CeO}_{2}$-based catalysts, which form superoxide species bound to differently coordinated metal cations (e.g., defect sites). Thus, the peak at $1040 \mathrm{~cm}^{-1}$ likely corresponds to an $\mathrm{Nb}^{\mathrm{IV}}-\left(\mathrm{O}_{2}\right)^{-}$(i.e., $\mathrm{Nb}$-superoxide) intermediate. Finally, all of the spectral features (Table 2) persist when $\mathrm{H}_{2} \mathrm{O}$ contacts the IRE (Fig. S11) after activation of $\mathrm{H}_{2} \mathrm{O}_{2}$ at $333 \mathrm{~K}$, which shows that the $\mathrm{Nb}^{\mathrm{IV}}-\left(\mathrm{O}_{2}\right)^{-}$ and $\mathrm{Nb}^{\mathrm{V}}-\mathrm{OOH} / \mathrm{Nb}^{\mathrm{V}}-\left(\mathrm{O}_{2}\right)^{2-}$ intermediates form irreversibly and do not spontaneously decompose in the presence of $\mathrm{H}_{2} \mathrm{O}$. This finding is also in agreement with results from DRUV-vis spectroscopy, discussed below, which are used to further identify and test the stability of these intermediates. The isomerization between hydroperoxide, peroxide, and superoxide intermediates has been proposed over TS-1 catalysts [65, 67], which suggests that interconversion between $\mathrm{Nb}^{\mathrm{V}}-\mathrm{OOH}, \mathrm{Nb}^{\mathrm{V}}-\left(\mathrm{O}_{2}\right)^{2-}$, and $\mathrm{Nb}^{\mathrm{IV}}-\left(\mathrm{O}_{2}\right)^{-}$species may also occur upon the irreversible activation of $\mathrm{H}_{2} \mathrm{O}_{2}$ (Scheme 1). For the purpose of brevity, $\mathrm{Nb}^{\mathrm{IV}}-\left(\mathrm{O}_{2}\right)^{-}$will be referred to as $\mathrm{Nb}^{\mathrm{IV}}-\left(\mathrm{O}_{2}\right)$ while $\mathrm{Nb}^{\mathrm{V}}-\mathrm{OOH}$ and $\mathrm{Nb}^{\mathrm{V}}-\left(\mathrm{O}_{2}\right)^{2-}$ will be collectively referred to as $\mathrm{Nb}^{\mathrm{V}}-\left(\mathrm{O}_{2}\right)$. 
Scheme 1. Activation of $\mathrm{H}_{2} \mathrm{O}_{2}$ to form $\mathrm{Nb}^{\mathrm{V}}-\mathrm{OOH}$ with the interconversion of $\mathrm{Nb}^{\mathrm{V}}-\mathrm{OOH}, \mathrm{Nb}^{\mathrm{V}}-$ $\left(\mathrm{O}_{2}\right)^{2-}$, and $\mathrm{Nb}^{\mathrm{IV}}-\left(\mathrm{O}_{2}\right)^{-}$. The oxidation state of each $\mathrm{Nb}$ center is depicted beneath the atom.

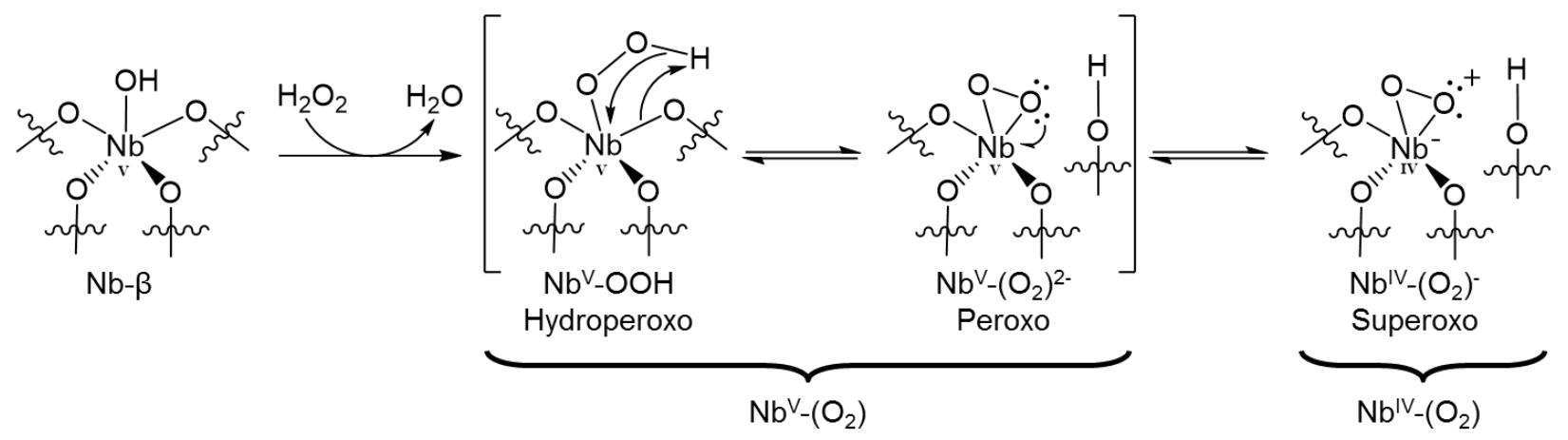

$\mathrm{X}$-ray photoelectron spectroscopy (XPS) was used to determine the oxidation state of $\mathrm{Nb}$ in both untreated and $\mathrm{H}_{2} \mathrm{O}_{2}$-activated (Section 2.4) $\mathrm{Nb}_{5.0}-\beta$ samples in order to verify the presence of $\mathrm{Nb}^{\mathrm{IV}}$ species (i.e., $\mathrm{Nb}^{\mathrm{IV}}-\left(\mathrm{O}_{2}\right)$ ). Figure $4 \mathrm{a}$ shows the XPS spectra for untreated $\mathrm{Nb}_{5.0}-\beta$ in the $\mathrm{Nb}$ $3 \mathrm{~d}$ region $(200-220 \mathrm{eV})$, which possesses a doublet with absorbance peaks centered at 210.6 and $208.0 \mathrm{eV}$ that correspond to $\mathrm{Nb}^{\mathrm{V}} 3 \mathrm{~d}_{3 / 2}$ and $3 \mathrm{~d}_{5 / 2}$, respectively [72, 73] (fitting that demonstrates the absence of $\mathrm{Nb}^{\mathrm{IV}}$ is provided in the SI, Fig. S7). These features shift to lower binding energies when the $\mathrm{Nb}_{5.0^{-}} \beta$ sample has been treated with $\mathrm{H}_{2} \mathrm{O}_{2}$ (details given in section 2.4). Figure $4 \mathrm{~b}$ shows that XPS spectra of $\mathrm{H}_{2} \mathrm{O}_{2}$-activated $\mathrm{Nb}_{5.0^{-}} \beta$ contains overlapping doublet features with doublets at 210.6 and $208.0 \mathrm{eV}$ as well as at 209.7 and $207.0 \mathrm{eV}$, which resemble reported values for $\mathrm{Nb}^{\mathrm{V}}$ and $\mathrm{Nb}^{\mathrm{IV}-}$ species [72], [73], and is consistent with the presence of the proposed $\mathrm{Nb}^{\mathrm{V}}-\left(\mathrm{O}_{2}\right)$ and $\mathrm{Nb}^{\mathrm{IV}}-\left(\mathrm{O}_{2}\right)$ species, respectively. Under ultra-high vacuum conditions (i.e., $10^{-9}$ Torr), the preferred state of the $\mathrm{H}_{2} \mathrm{O}_{2}$-activated $\mathrm{Nb}-\beta$ is $\mathrm{Nb}^{\mathrm{IV}}-\left(\mathrm{O}_{2}\right)$, because the lack of free protons favors the formation of the superoxo species, as shown for $\mathrm{H}_{2} \mathrm{O}_{2}$-activated TS-1 [66], which explains why the magnitude of the features for $\mathrm{Nb}^{\mathrm{IV}}$ is much larger than for $\mathrm{Nb}^{\mathrm{V}}$ on $\mathrm{H}_{2} \mathrm{O}_{2}$-treated materials. 


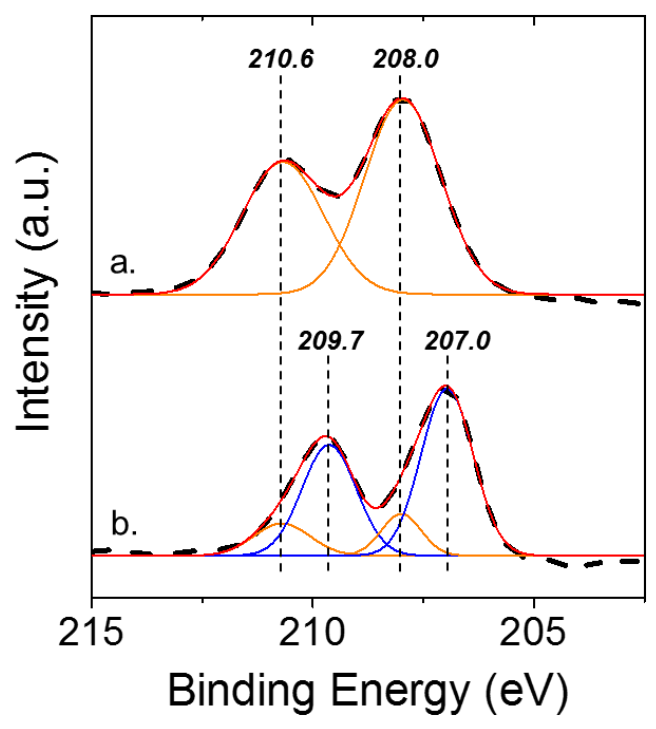

Figure 4. X-ray photoelectron spectra (black, dashed) of the $\mathrm{Nb} 3 \mathrm{~d}$ region with peak fittings (colored, solid) for (a) untreated $\mathrm{Nb}_{5.0}-\beta$ and (b) $\mathrm{H}_{2} \mathrm{O}_{2}$-treated $\mathrm{Nb}_{5.0}-\beta$. The peak fittings from the different oxidation states are color-coded for clarity: $\mathrm{Nb}^{\mathrm{IV}}$ (blue, -), $\mathrm{Nb}^{\mathrm{V}}$ (orange, -), and cumulative peak fit (red, - ). Spectra are referenced to an aliphatic $\mathrm{C} 1 \mathrm{~s}$ feature at $284.8 \mathrm{eV}$. The $\mathrm{H}_{2} \mathrm{O}_{2}$ treatment procedure is described in section 2.4. 


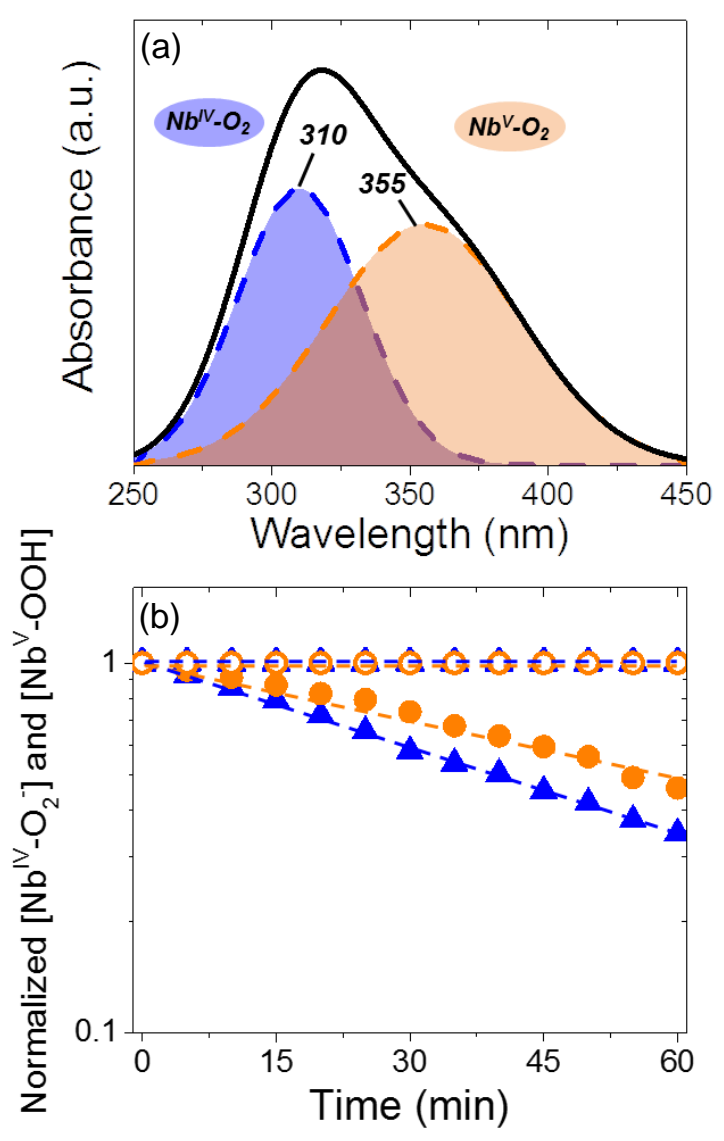

Figure 5. (a) UV-vis spectra of $\mathrm{H}_{2} \mathrm{O}_{2}$-treated $\mathrm{Nb}_{0.3}-\beta$ in flowing $\mathrm{CH}_{3} \mathrm{CN}\left(0.4 \mathrm{M} \mathrm{H}_{2} \mathrm{O}\right)$ at $348 \mathrm{~K}(-$ , black), and deconvoluted peaks (dashed) centered at 301 (-, blue) and $365 \mathrm{~nm}$ (-, orange); and (b) changes in the normalized coverages of $\left[\mathrm{Nb}^{\mathrm{IV}}-\left(\mathrm{O}_{2}\right)\right](330 \mathrm{~nm}, \boldsymbol{\Delta})$ and $\left[\mathrm{Nb}^{\mathrm{V}}-\left(\mathrm{O}_{2}\right)\right](370 \mathrm{~nm}, \bullet)$ as a function of time after contact with $\mathrm{C}_{6} \mathrm{H}_{10}$ in $\mathrm{CH}_{3} \mathrm{CN}\left(0.1 \mathrm{M} \mathrm{C}_{6} \mathrm{H}_{10}, 0.4 \mathrm{M} \mathrm{H}_{2} \mathrm{O}, 1 \mathrm{~cm}^{3} \mathrm{~min}^{-1}\right.$, closed symbols) or pure DI $\mathrm{H}_{2} \mathrm{O}\left(1 \mathrm{~cm}^{3} \mathrm{~min}^{-1}\right.$, open symbols $)$ at $313 \mathrm{~K}$. Dashed lines are intended to guide the eye.

The surface intermediates (i.e., $\mathrm{Nb}^{\mathrm{IV}}-\left(\mathrm{O}_{2}\right)$ and $\mathrm{Nb}^{\mathrm{V}}-\left(\mathrm{O}_{2}\right)$ ) generated by reacting $\mathrm{Nb}_{0.3}-\beta$ with $\mathrm{H}_{2} \mathrm{O}_{2}$ appear as distinct absorption features in in situ DRUV-vis spectroscopy. Figure 5a shows a UV-vis spectrum of $\mathrm{H}_{2} \mathrm{O}_{2}$-treated $\mathrm{Nb}_{0.3}-\beta$ (section 2.5), which contains two distinct absorbance bands at 310 and $355 \mathrm{~nm}$ that are assigned to $\mathrm{Nb}^{\mathrm{IV}}-\left(\mathrm{O}_{2}\right)$ and $\mathrm{Nb}^{\mathrm{V}}-\left(\mathrm{O}_{2}\right)$ moieties, respectively [67, 69]. Figure $5 b$ shows that the normalized intensities of the $\mathrm{Nb}^{\mathrm{IV}}-\left(\mathrm{O}_{2}\right)(310 \mathrm{~nm})$ and $\mathrm{Nb}^{\mathrm{V}}-\left(\mathrm{O}_{2}\right)$ (355 nm) features decrease with an exponential dependence on time when the $\mathrm{H}_{2} \mathrm{O}_{2}$-treated 
$\mathrm{Nb}_{0.3}-\beta$ contacts a flowing solution of $\mathrm{C}_{6} \mathrm{H}_{10}$ in $\mathrm{CH}_{3} \mathrm{CN}\left(0.1 \mathrm{M} \mathrm{C}_{6} \mathrm{H}_{10}, 0.4 \mathrm{M} \mathrm{H}_{2} \mathrm{O}, 1 \mathrm{~cm}^{3} \min ^{-1}\right)$. However, Figure 5b shows also that neither the 310 or $355 \mathrm{~nm}$ absorbance feature change noticeably even after one hr of contact with a flowing stream of pure DI $\mathrm{H}_{2} \mathrm{O}\left(1 \mathrm{~cm}^{3} \mathrm{~min}^{-1}\right)$, which demonstrates further that these intermediates (i.e., $\mathrm{Nb}^{\mathrm{IV}}-\left(\mathrm{O}_{2}\right)$ or $\mathrm{Nb}^{\mathrm{V}}-\left(\mathrm{O}_{2}\right)$ ) form irreversibly. These data, along with steady-state IR spectra obtained under a flow of $\mathrm{H}_{2} \mathrm{O}$ (Fig. S11), strongly suggest that $\mathrm{Nb}-\beta$ activates $\mathrm{H}_{2} \mathrm{O}_{2}$ irreversibly to form both $\mathrm{Nb}^{\mathrm{IV}}-\left(\mathrm{O}_{2}\right)$ and $\mathrm{Nb}^{\mathrm{V}}-$ $\left(\mathrm{O}_{2}\right)$ intermediates, in contrast to proposed mechanisms on similar Ti- and Ta-based catalysts, where $\mathrm{H}_{2} \mathrm{O}_{2}$ activation is proposed to occur reversibly (and often in a quasi-equilibrated fashion) $[21-23,39]$.

Scheme 2. Formation and consumption of active species on $\mathrm{Nb}-\beta . \mathrm{Nb}^{\mathrm{V}}-\left(\mathrm{O}_{2}\right)\left(\mathrm{Nb}^{\mathrm{IV}}-\mathrm{OOH}\right.$ shown $)$ and $\mathrm{Nb}^{\mathrm{IV}}-\left(\mathrm{O}_{2}\right)$ form upon reaction of $\mathrm{H}_{2} \mathrm{O}_{2}$ with $\mathrm{Nb}-\beta$, and these species interconvert, and may be consumed by reaction with $\mathrm{C}_{6} \mathrm{H}_{10}$.

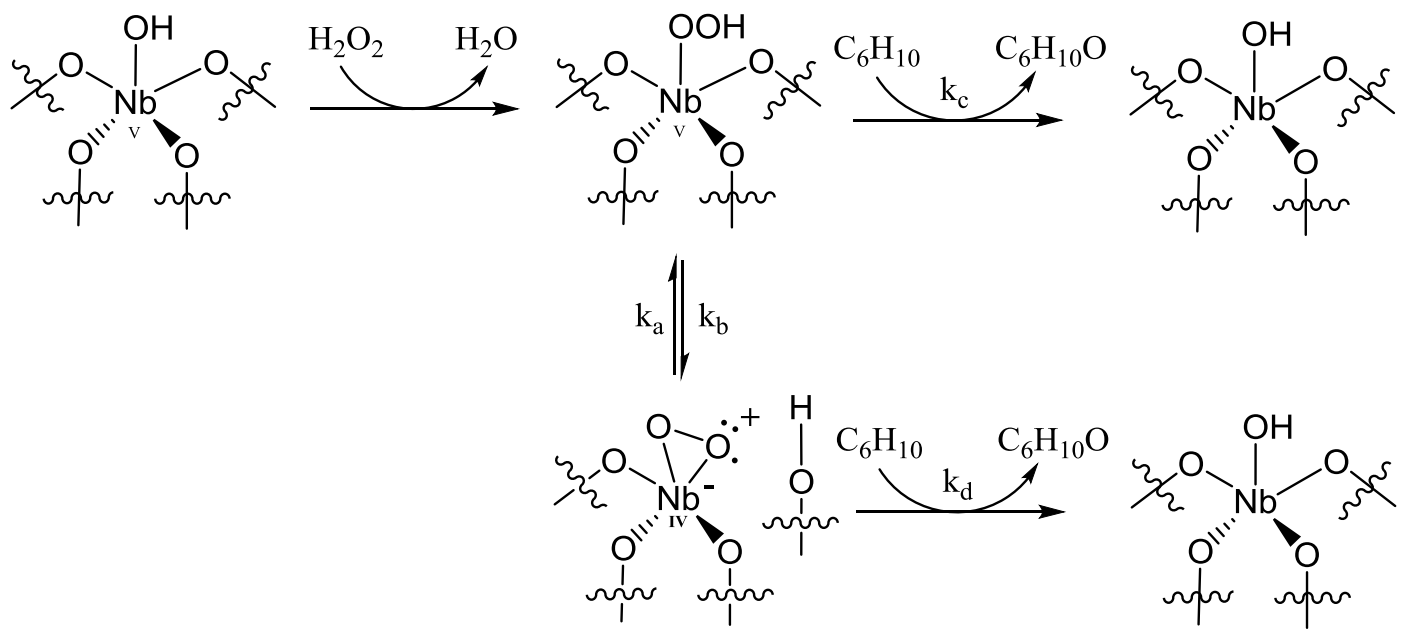

${ }^{\mathrm{a}}$ Formation of $\mathrm{Nb}^{\mathrm{V}}-\left(\mathrm{O}_{2}\right)$ and $\mathrm{Nb}^{\mathrm{IV}}-\left(\mathrm{O}_{2}\right)$ occurs during the activation of $\mathrm{H}_{2} \mathrm{O}_{2}$ over $\mathrm{Nb}_{0.3}-\beta$ by flow of $\mathrm{H}_{2} \mathrm{O}_{2}$ in $\mathrm{CH}_{3} \mathrm{CN}$ (Section 2.5).

The intensity of these two UV-vis features (Fig. 5a, 310 and $355 \mathrm{~nm}$, normalized by their initial intensities) attenuate with an exponential dependence on time at different rates when 
$\mathrm{H}_{2} \mathrm{O}_{2}$-treated $\mathrm{Nb}_{0.3}-\beta$ contacts a solution of $\mathrm{C}_{6} \mathrm{H}_{10}$ in $\mathrm{CH}_{3} \mathrm{CN}\left(0.1 \mathrm{M} \mathrm{C}_{6} \mathrm{H}_{10}, 0.4 \mathrm{M} \mathrm{H}_{2} \mathrm{O}, 1 \mathrm{~cm}^{3}\right.$ $\min ^{-1}$ ), and the differences in the rates of consumption of these species reflect the nature of the elementary steps that consume $\mathrm{Nb}^{\mathrm{IV}}-\left(\mathrm{O}_{2}\right)$ and $\mathrm{Nb}^{\mathrm{V}}-\left(\mathrm{O}_{2}\right)$ (Scheme 2). $\mathrm{Nb}^{\mathrm{IV}}-\left(\mathrm{O}_{2}\right)$ and $\mathrm{Nb}^{\mathrm{V}}-\left(\mathrm{O}_{2}\right)$ species may be consumed by reaction with $\mathrm{C}_{6} \mathrm{H}_{10}$, but these species may also interconvert during the course of the reaction, as shown in Schemes 1 and 2 [65]. Consequently, the change in coverage of $\mathrm{Nb}^{\mathrm{IV}}-\left(\mathrm{O}_{2}\right)$ and $\mathrm{Nb}^{\mathrm{V}}-\left(\mathrm{O}_{2}\right)$ depends on the summed rates of formation and consumption of each species, which take the forms of:

$$
\begin{gathered}
\frac{d\left[N b^{N}-\left(O_{2}\right)\right]}{d t}=k_{a}\left[N b^{V}-\left(O_{2}\right)\right]-k_{b}\left[N b^{N}-\left(O_{2}\right)\right]-k_{d}\left[N b^{N V}-\left(O_{2}\right)\right]\left[C_{6} H_{10}\right] \\
\frac{d\left[N b^{V}-\left(O_{2}\right)\right]}{d t}=k_{b}\left[N b^{I V}-\left(O_{2}\right)\right]-k_{a}\left[N b^{V}-\left(O_{2}\right)\right]-k_{c}\left[N b^{V}-\left(O_{2}\right)\right]\left[C_{6} H_{10}\right]
\end{gathered}
$$

where $\left[\mathrm{Nb}^{\mathrm{IV}}-\left(\mathrm{O}_{2}\right)^{-}\right]$and $\left[\mathrm{Nb}^{\mathrm{V}}-\left(\mathrm{O}_{2}\right)\right]$ represents the coverage of $\mathrm{Nb}^{\mathrm{IV}}-\left(\mathrm{O}_{2}\right)$ and $\mathrm{Nb}^{\mathrm{V}}-\left(\mathrm{O}_{2}\right),\left[\mathrm{C}_{6} \mathrm{H}_{10}\right]$ is the concentration of $\mathrm{C}_{6} \mathrm{H}_{10}, \mathrm{k}_{\mathrm{a}}$ is the rate constant for the interconversion of $\mathrm{Nb}^{\mathrm{V}}-\left(\mathrm{O}_{2}\right)$ to $\mathrm{Nb}^{\mathrm{IV}}$ $\left(\mathrm{O}_{2}\right), \mathrm{k}_{\mathrm{b}}$ is the rate constant for the interconversion of $\mathrm{Nb}^{\mathrm{IV}}-\left(\mathrm{O}_{2}\right)$ to $\mathrm{Nb}^{\mathrm{V}}-\left(\mathrm{O}_{2}\right)$, and $\mathrm{k}_{\mathrm{c}}$ and $\mathrm{k}_{\mathrm{d}}$ are the rate constants for the epoxidation of $\mathrm{C}_{6} \mathrm{H}_{10}$ with $\mathrm{Nb}^{\mathrm{V}}-\left(\mathrm{O}_{2}\right)$ and $\mathrm{Nb}^{\mathrm{IV}}-\left(\mathrm{O}_{2}\right)$, respectively. Pseudo first-order kinetics are assumed for the reaction of $\mathrm{Nb}^{\mathrm{V}}-\left(\mathrm{O}_{2}\right)$ and $\mathrm{Nb}^{\mathrm{IV}}-\left(\mathrm{O}_{2}\right)$ with $\mathrm{C}_{6} \mathrm{H}_{10}$, and $\left[\mathrm{C}_{6} \mathrm{H}_{10}\right]$ is constant because $\mathrm{C}_{6} \mathrm{H}_{10}$ flows continuously through the reactor and conversion of $\mathrm{C}_{6} \mathrm{H}_{10}$ is negligible. MATLAB ${ }^{\mathrm{TM}}$ is used to numerically solve these two coupled differential equations (equations 2 and 3), while iteratively optimizing the rate constants (i.e., $\mathrm{k}_{\mathrm{i}}$ ) to fit the experimental data (Section S3.2), and Table 3 shows the optimized rate constants for Scheme 2. The value of $\mathrm{k}_{\mathrm{d}}$ is calculated to be $\sim 2 \cdot 10^{4}$ times that of $\mathrm{k}_{\mathrm{c}}$, which shows directly that $\mathrm{Nb}^{\mathrm{IV}}-\left(\mathrm{O}_{2}\right)$ is the reactive species that is responsible for all observed epoxidation rates and that this species is more than four orders of magnitude more reactive than the $\mathrm{Nb}^{\mathrm{V}}-\left(\mathrm{O}_{2}\right)$ species. The consumption of $\mathrm{Nb}^{\mathrm{V}}-\left(\mathrm{O}_{2}\right)$ is, therefore, attributed to its interconversion to reform additional $\mathrm{Nb}^{\mathrm{IV}}-\left(\mathrm{O}_{2}\right)$ 
throughout the course of the reaction (i.e., value of $\mathrm{k}_{\mathrm{b}}$ significantly greater than $\mathrm{k}_{\mathrm{a}}$ ). Collectively, these data show that both $\mathrm{Nb}^{\mathrm{IV}}-\left(\mathrm{O}_{2}\right)$ and $\mathrm{Nb}^{\mathrm{V}}-\left(\mathrm{O}_{2}\right)$ are formed upon activation of $\mathrm{H}_{2} \mathrm{O}_{2}$, but only $\mathrm{Nb}^{\mathrm{IV}}-\left(\mathrm{O}_{2}\right)$ participates directly in the epoxidation of $\mathrm{C}_{6} \mathrm{H}_{10}$, while $\mathrm{Nb}^{\mathrm{V}}-\left(\mathrm{O}_{2}\right)$ simply interconverts to partially replenish $\mathrm{Nb}^{\mathrm{IV}}-\left(\mathrm{O}_{2}\right)$ during reaction.

Table 3. Numerically optimized rate constants $\mathrm{k}_{\mathrm{i}}$ for the interconversion of $\mathrm{Nb}^{\mathrm{V}}-\left(\mathrm{O}_{2}\right)$ and $\mathrm{Nb}^{\mathrm{IV}}$ $\left(\mathrm{O}_{2}\right)$ and reaction with $\mathrm{C}_{6} \mathrm{H}_{10}$ (Scheme 2). See Section S3.2 for a complete description of the procedure used to optimize parameters and fit the experimental data.

\begin{tabular}{cc}
\hline $\mathrm{k}_{\mathrm{i}}$ & Numerically Optimized Value $\left(\mathrm{min}^{-1}\right)$ \\
\hline $\mathrm{k}_{\mathrm{a}}$ & $2.3 \cdot 10^{-4}$ \\
$\mathrm{k}_{\mathrm{b}}$ & $2.0 \cdot 10^{-2}$ \\
$\mathrm{k}_{\mathrm{c}}$ & $1.3 \cdot 10^{-5}$ \\
$\mathrm{k}_{\mathrm{d}}$ & $2.7 \cdot 10^{-1}$
\end{tabular}



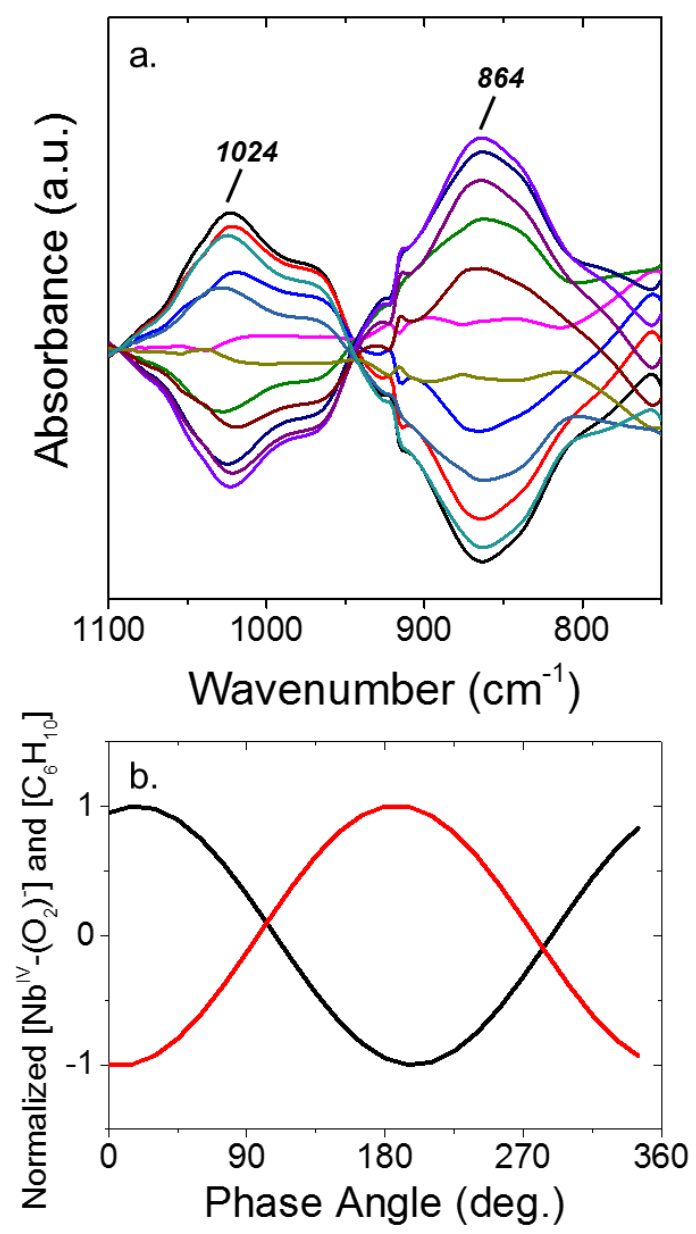

Figure 6. (a) Phase-angle resolved in situ FTIR spectra showing spectral contributions of active surface species for $\mathrm{C}_{6} \mathrm{H}_{10}$ epoxidation on $\mathrm{Nb}_{1.5}-\beta$, and (b) Normalized $\mathrm{Nb}^{\mathrm{IV}}-\left(\mathrm{O}_{2}\right)^{-}\left(1024 \mathrm{~cm}^{-1}\right.$, black, - ) and $\mathrm{C}_{6} \mathrm{H}_{10}\left(864 \mathrm{~cm}^{-1}\right.$, red, -) IR-feature absorbances as a function of phase angle. Spectra were obtained while sinusoidally modulating the flowrates of $\mathrm{C}_{6} \mathrm{H}_{10}\left(0.1 \mathrm{M} \mathrm{C}_{6} \mathrm{H}_{10}\right.$ in $\left.\mathrm{CH}_{3} \mathrm{CN}\right)$ and $\mathrm{H}_{2} \mathrm{O}_{2}\left(0.065 \mathrm{H}_{2} \mathrm{O}_{2}\right.$ in $\left.\mathrm{CH}_{3} \mathrm{CN}\right)$ solutions $\left(0.5 \mathrm{~cm}^{3}\right.$ total volumetric flowrate, $333 \mathrm{~K}$, Section 2.5). Lines correspond to FTIR spectra obtained at $30^{\circ}$ increments of the demodulation phase angle.

Modulation excitation spectroscopy (MES) experiments were employed to support the conclusion that $\mathrm{Nb}^{\mathrm{IV}}-\left(\mathrm{O}_{2}\right)$ is the active intermediate for the epoxidation of $\mathrm{C}_{6} \mathrm{H}_{10}$. The flow rates $\mathrm{H}_{2} \mathrm{O}_{2}$ and cyclohexene in $\mathrm{CH}_{3} \mathrm{CN}$ (Section 2.5) were modulated sinusoidally with the intent to periodically populate the catalyst surface with the active species (i.e., $\mathrm{Nb}^{\mathrm{IV}}-\left(\mathrm{O}_{2}\right)$ and $\mathrm{Nb}^{\mathrm{V}}-\left(\mathrm{O}_{2}\right)$ ) 
and subsequently consume these species by cyclohexene epoxidation. Figure 6a displays phase domain spectra (obtained by resampling all spectra into a single period, converting to the phase domain, and employing phase sensitive detection, see Section S4.1), that show only the active surface species whose coverages change at frequencies comparable to the modulation (i.e., contributions from spectator species are suppressed). Figure 6 shows a broad feature at $864 \mathrm{~cm}^{-1}$ that is assigned to $v(C-C)$ of a $\mathrm{C}_{6}$ ring of either $\mathrm{C}_{6} \mathrm{H}_{10}$ or $\mathrm{C}_{6} \mathrm{H}_{10} \mathrm{O}$ [74]. Notably, this broad 864 $\mathrm{cm}^{-1}$ feature is perfectly out of phase (i.e., $180^{\circ}$ phase shift) with the absorbance feature corresponding to the active $\mathrm{Nb}^{\mathrm{IV}}-\left(\mathrm{O}_{2}\right)$ intermediate $\left(1024 \mathrm{~cm}^{-1}\right.$, Fig. $\left.6 \mathrm{~b}\right)$, which supports the conclusion that $\mathrm{Nb}^{\mathrm{IV}}-\left(\mathrm{O}_{2}\right)$ species are consumed by reaction with $\mathrm{C}_{6} \mathrm{H}_{10}$, which is followed by the replacement of $\mathrm{Nb}^{\mathrm{IV}}-\left(\mathrm{O}_{2}\right)$ with $\mathrm{C}_{6} \mathrm{H}_{10}$ or $\mathrm{C}_{6} \mathrm{H}_{10} \mathrm{O}$ as the MARI on the catalyst surface. Unfortunately, the spectroscopic feature at $845 \mathrm{~cm}^{-1}$ attributed to $\mathrm{Nb}^{\mathrm{V}}-\left(\mathrm{O}_{2}\right)\left(\right.$ Fig. $\left.3 b, \mathrm{Nb}^{\mathrm{V}}-\left(\mathrm{O}_{2}\right)\right)$ is overwhelmed by the broad feature at $864 \mathrm{~cm}^{-1}$, which precludes clear analysis of how the coverage of $\mathrm{Nb}^{\mathrm{V}}-\left(\mathrm{O}_{2}\right)$ species vary with the changes in the concentrations of $\mathrm{C}_{6} \mathrm{H}_{10}$ and $\mathrm{H}_{2} \mathrm{O}_{2}$. However, the previous analysis of the in situ UV-vis spectra (Figure 5, Table 3) shows already that the $\mathrm{Nb}^{\mathrm{V}}-\left(\mathrm{O}_{2}\right)$ intermediates do not directly participate in epoxidation reactions. In summary, the combined in situ FTIR and UV-vis data (Figures 3, 5-6) suggest that $\mathrm{H}_{2} \mathrm{O}_{2}$-activation over $\mathrm{Nb}_{1.5}-\beta$ occurs irreversibly and that $\mathrm{Nb}^{\mathrm{IV}}-\left(\mathrm{O}_{2}\right)$ (and not $\mathrm{Nb}^{\mathrm{V}}-\left(\mathrm{O}_{2}\right)$ ) is the active intermediate for $\mathrm{C}_{6} \mathrm{H}_{10}$ epoxidation upon activation of $\mathrm{H}_{2} \mathrm{O}_{2}$ by Nb- $\beta$.

The conclusion that $\mathrm{Nb}^{\mathrm{IV}}-\left(\mathrm{O}_{2}\right)$ is the active species for olefin epoxidation is not immediately intuitive, because superoxide species are typically though to be one electron oxidants (or even reductants) and not two-electron (2e $)$ oxidants. In order for $\mathrm{Nb}-\left(\mathrm{O}_{2}\right)$ to undergo a $2 \mathrm{e}^{-}$oxidation (e.g., olefin epoxidation), the process must involve concomitant oxidation of the Nb-metal center from $\mathrm{Nb}^{\mathrm{IV}}$ to $\mathrm{Nb}^{\mathrm{V}}$ and the reformation of a Nb-O-Si framework bond. Similar processes have 
been proposed to occur through a biradical, stepwise reaction on homogeneous vanadium complexes $[75,76]$, and $\mathrm{Nb}-\left(\mathrm{O}_{2}\right)^{-}$superoxide species may react in an analogous manner (Scheme S2). The epoxidation of cis-stilbene provides one method to test this hypothesis and to determine whether the epoxidation reaction proceeds through a concerted reaction or by a stepwise reaction, which would be consistent with the participation of $\mathrm{Nb}^{\mathrm{IV}}-\left(\mathrm{O}_{2}\right)$ as the active intermediate [77]. The reaction of cis-stilbene with $\mathrm{Nb}_{1.5}-\beta\left(0.01 \mathrm{M}\right.$ cis-stilbene, $0.01 \mathrm{M} \mathrm{H}_{2} \mathrm{O}_{2}$, in $\mathrm{CH}_{3} \mathrm{CN}, 323$ K) produces nearly equimolar quantities of cis- and trans-stilbene oxides (the exact ratio of cisto trans-stilbene oxide is equal to 0.96 ). This equimolar ratio suggests that olefin epoxidation over Nb- $\beta$ occurs through the biradical stepwise mechanism (e.g., Scheme S2), which provides sufficient time for the coordinated olefin intermediate to isomerize about the central $\mathrm{C}=\mathrm{C}$ bond prior to oxirane cyclization. Collectively, these spectroscopic data and product selectivities provide compelling evidence that $\mathrm{H}_{2} \mathrm{O}_{2}$ irreversibly activates over $\mathrm{Nb}-\beta$ to form a pool of $\mathrm{Nb}^{\mathrm{V}}$ $\left(\mathrm{O}_{2}\right)$ and $\mathrm{Nb}^{\mathrm{IV}}-\left(\mathrm{O}_{2}\right)$ species that interconvert, and that from this pool, $\mathrm{Nb}^{\mathrm{IV}}-\left(\mathrm{O}_{2}\right)$ species participate directly in the epoxidation of olefins by a biradical, stepwise reaction pathway (Scheme S2). 


\subsection{Dependence of Turnover Rates on Reactant Concentrations and Mechanistic Interpretation}
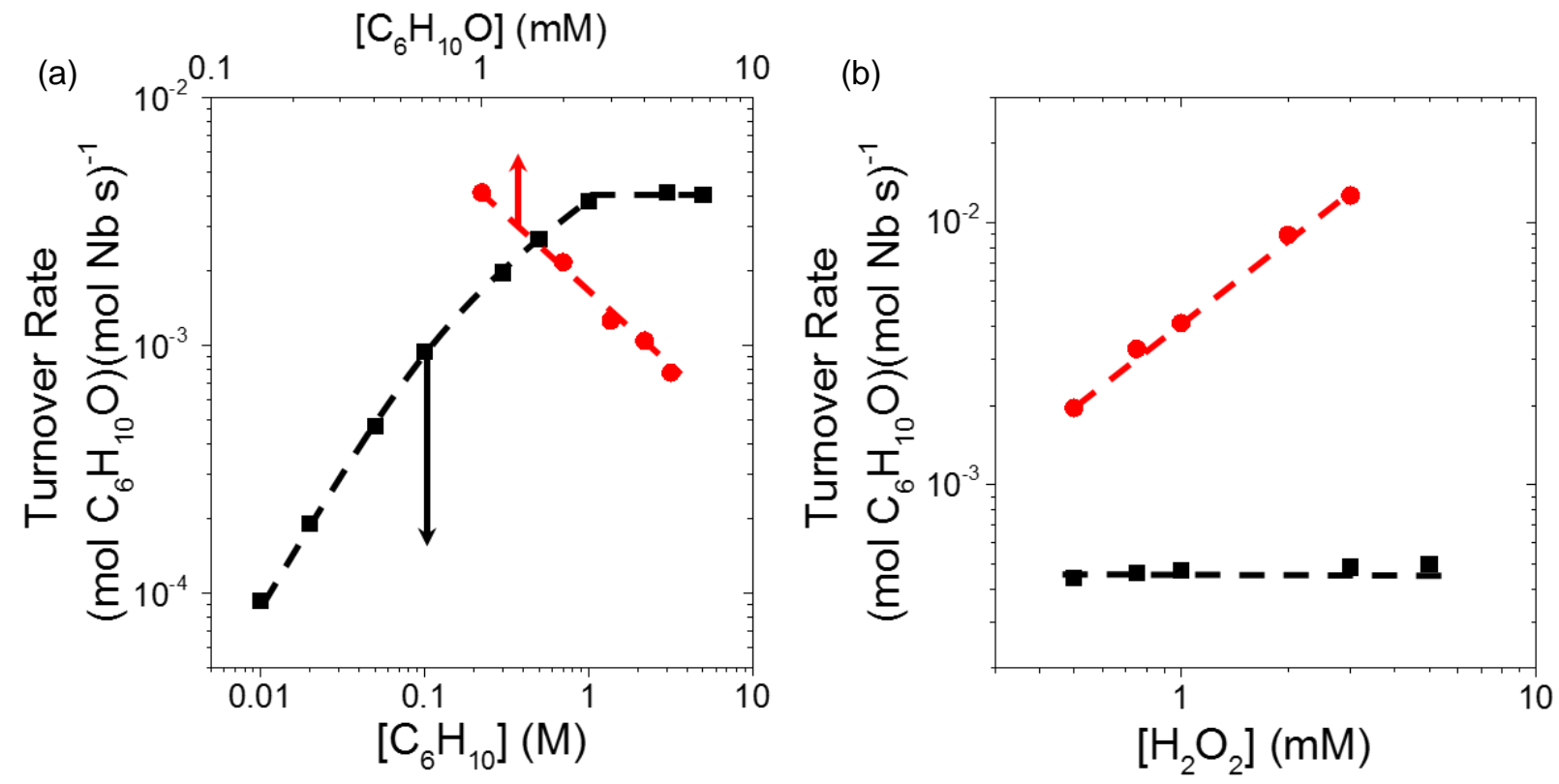

Figure 7. Turnover rates for the formation of $\mathrm{C}_{6} \mathrm{H}_{10} \mathrm{O}$ as a function of (a) $\left[\mathrm{C}_{6} \mathrm{H}_{10}\right](\mathbf{m}, 1 \mathrm{mM}$ $\left.\mathrm{H}_{2} \mathrm{O}_{2}, \mathrm{Nb}_{1.5}-\beta, 313 \mathrm{~K}\right)$ and $\left[\mathrm{C}_{6} \mathrm{H}_{10} \mathrm{O}\right]\left(\bullet, 3 \mathrm{M} \mathrm{C}_{6} \mathrm{H}_{10}, 1 \mathrm{mM} \mathrm{H}_{2} \mathrm{O}_{2}, \mathrm{Nb}_{1.5}-\beta\right.$, balance $\mathrm{CH}_{3} \mathrm{CN}$ to 30 $\left.\mathrm{cm}^{3}, 313 \mathrm{~K}\right)$ and (b) as a function of $\left[\mathrm{H}_{2} \mathrm{O}_{2}\right]\left(50 \mathrm{mM} \mathrm{C} \mathrm{C}_{6} \mathrm{H}_{10}(\boldsymbol{\bullet})\right.$ or $3 \mathrm{M} \mathrm{C}_{6} \mathrm{H}_{10}(\bullet), \mathrm{Nb}_{1.5}-\beta, 313$ $\mathrm{K})$. Error bars omitted for clarity, and lines are intended to guide the eye.

Figure 7a shows turnover rates for the formation of $\mathrm{C}_{6} \mathrm{H}_{10} \mathrm{O}$ as a function of $\left[\mathrm{C}_{6} \mathrm{H}_{10}\right](0.01-5$ $\mathrm{M} \mathrm{C}_{6} \mathrm{H}_{10}, 1 \mathrm{mM} \mathrm{H} \mathrm{O}_{2}, 313 \mathrm{~K}$ ) over $\mathrm{Nb}_{1.5}-\beta$, and Figure $7 \mathrm{~b}$ shows turnover rates for $\mathrm{C}_{6} \mathrm{H}_{10} \mathrm{O}$ formation as a function of $\left[\mathrm{H}_{2} \mathrm{O}_{2}\right]\left(0.5-5 \mathrm{mM} \mathrm{H}_{2} \mathrm{O}_{2}, 0.05\right.$ and $\left.3 \mathrm{M} \mathrm{C}_{6} \mathrm{H}_{10}, 313 \mathrm{~K}\right)$. Rates of epoxidation depend linearly on $\left[\mathrm{C}_{6} \mathrm{H}_{10}\right]$ and do not change with $\left[\mathrm{H}_{2} \mathrm{O}_{2}\right](0.5-5 \mathrm{mM}, 5 \mathrm{mM}$ $\left.\mathrm{C}_{6} \mathrm{H}_{10}\right)$ at low $\left[\mathrm{C}_{6} \mathrm{H}_{10}\right]\left(0.01-0.1 \mathrm{M} \mathrm{C}_{6} \mathrm{H}_{10}\right)$, which suggests that the active sites are saturated with an $\mathrm{H}_{2} \mathrm{O}_{2}$-derived intermediate, such as adsorbed $\mathrm{H}_{2} \mathrm{O}_{2}$ or $\mathrm{Nb}^{\mathrm{IV}}-\left(\mathrm{O}_{2}\right) / \mathrm{Nb}^{\mathrm{V}}-\left(\mathrm{O}_{2}\right)$ (section 3.1). Rates of epoxidation become independent of $\left[\mathrm{C}_{6} \mathrm{H}_{10}\right]$ as $\left[\mathrm{C}_{6} \mathrm{H}_{10}\right]$ increases further $(0.1-5 \mathrm{M}$ $\mathrm{C}_{6} \mathrm{H}_{10}$ ), and this change indicates that the identity of the MARI changes to a $\mathrm{C}_{6} \mathrm{H}_{10}$-derived intermediate (e.g., $\mathrm{C}_{6} \mathrm{H}_{10}$ or $\mathrm{C}_{6} \mathrm{H}_{10} \mathrm{O}$ ). This is likely due to the increasing amount of $\mathrm{C}_{6} \mathrm{H}_{10^{-}}$ 
derived species (i.e., $\mathrm{C}_{6} \mathrm{H}_{10}$ or $\mathrm{C}_{6} \mathrm{H}_{10} \mathrm{O}$ ) occupying additional $\mathrm{Nb}$ active sites which decreases the number of sites that exist as the active $\mathrm{Nb}^{\mathrm{IV}}-\left(\mathrm{O}_{2}\right)^{-}$species. Additionally, Figure $7 \mathrm{~b}$ shows the turnover rates become proportional to $\left[\mathrm{H}_{2} \mathrm{O}_{2}\right](0.5-3 \mathrm{mM})$ at higher $\left[\mathrm{C}_{6} \mathrm{H}_{10}\right](3 \mathrm{M})$, which is consistent with a change in the MARI from an $\mathrm{H}_{2} \mathrm{O}_{2}$-derived intermediate to a $\mathrm{C}_{6} \mathrm{H}_{10}$-derived MARI. Figure $7 \mathrm{a}$ shows that the rate of epoxidation depends inversely on the $\mathrm{C}_{6} \mathrm{H}_{10} \mathrm{O}$ concentration $(1-5 \mathrm{mM})$ within this same range of $\left[\mathrm{C}_{6} \mathrm{H}_{10}\right](3 \mathrm{M})$ and $\left[\mathrm{H}_{2} \mathrm{O}_{2}\right](1 \mathrm{mM})$, which implies that $\mathrm{C}_{6} \mathrm{H}_{10} \mathrm{O}$ binds strongly to the active site and inhibits rates.

Previously proposed mechanisms for olefin epoxidation on metal-oxide catalysts (i.e., TS-1 [39] and Ta-SBA-15 [21, 22]) assume that steps for the adsorption of the olefin, $\mathrm{H}_{2} \mathrm{O}_{2}$, epoxide, and the formation of the reactive intermediate (e.g., $\mathrm{M}-\mathrm{OOH}$ or $\left.\mathrm{M}-\left(\mathrm{O}_{2}\right)^{-}\right)$are quasi-equilibrated (QE) and that the epoxidation of the olefin by the M- $\left(\mathrm{O}_{2}\right)$ species is the sole kinetically relevant (KR) step. Such mechanisms give rate expressions (Section S5 contains the rate expressions based on these previous models) that predict epoxide formation rates that do not depend on $\left[\mathrm{H}_{2} \mathrm{O}_{2}\right]$ and increase linearly with $\left[\mathrm{C}_{6} \mathrm{H}_{10}\right]$ at low $\left[\mathrm{C}_{6} \mathrm{H}_{10}\right]$ (equation S5.6), and that reaction rates become constant with $\left[\mathrm{C}_{6} \mathrm{H}_{10}\right]$ but proportional to $\left[\mathrm{H}_{2} \mathrm{O}_{2}\right]$ at greater $\left[\mathrm{C}_{6} \mathrm{H}_{10}\right]$ (equation S5.7). The previously described mechanisms and rate expressions for cyclohexene and cyclooctene epoxidation on TS-1 [39] and $\mathrm{Ta}_{-} \mathrm{SiO}_{2}[21,22]$ are consistent with the rate data shown here (Fig. $7 \mathrm{a}$ and $7 \mathrm{~b}$ ) as a function of $\left[\mathrm{H}_{2} \mathrm{O}_{2}\right]$ and $\left[\mathrm{C}_{6} \mathrm{H}_{10}\right]$, but fail to predict the dependence on $\left[\mathrm{C}_{6} \mathrm{H}_{10} \mathrm{O}\right]$. These previous studies did not report changes in rates as a function of the epoxide concentration. Several aspects of the previously proposed mechanisms are inconsistent with the results shown in this article (and perhaps with chemical intuition). The in situ FTIR and UV-vis spectra show that neither the $\mathrm{Nb}^{\mathrm{IV}}-\left(\mathrm{O}_{2}\right)$ or the $\mathrm{Nb}^{\mathrm{V}}-\left(\mathrm{O}_{2}\right)$ species decompose or reform $\mathrm{H}_{2} \mathrm{O}_{2}$ in the presence of $\mathrm{H}_{2} \mathrm{O}$ (Section 3.1), which demonstrate that these intermediates form irreversibly (Scheme 3, step 
3) when $\mathrm{H}_{2} \mathrm{O}_{2}$ reacts with the metal center (e.g., Nb). Notably, these results disagree with previous assumptions that $\mathrm{M}-\left(\mathrm{O}_{2}\right)$ species form on Ti- and Ta-based catalysts by QE processes $[21,22,39]$. Chemical intuition also suggests that $\mathrm{H}_{2} \mathrm{O}_{2}$ is not likely to reform from the $\mathrm{Nb}^{\mathrm{IV}}$ $\left(\mathrm{O}_{2}\right)$ and $\mathrm{Si}-\mathrm{OH}$ groups (created by hydroperoxidolysis of the $\mathrm{Nb}-\mathrm{O}$ bond) when the sample is hydrated (Scheme 3, reverse step 3), because the formation of $\mathrm{H}_{2} \mathrm{O}_{2}$ from $\mathrm{H}_{2} \mathrm{O}$ and the surface function is most likely endothermic and thermodynamically disfavored under these conditions. Therefore, the mechanism shown below (Scheme 3) differs from previous proposals in a few significant ways. 
Scheme 3. Proposed mechanism for cyclohexene epoxidation with $\mathrm{H}_{2} \mathrm{O}_{2}$ over Nb- $\beta$. Subscripts for rate constants or equilibrium constants $\left(\mathrm{k}_{\mathrm{x}}\right.$ or $\mathrm{K}_{\mathrm{x}}$, respectively) denote the number of the elementary step. The proposal for an active $\mathrm{Nb}^{\mathrm{IV}}-\left(\mathrm{O}_{2}\right)$ intermediate is supported by XPS (Fig. 4) and time-resolved in situ FTIR (Fig. 3 and 6) and UV-vis spectroscopy (Fig. 5).

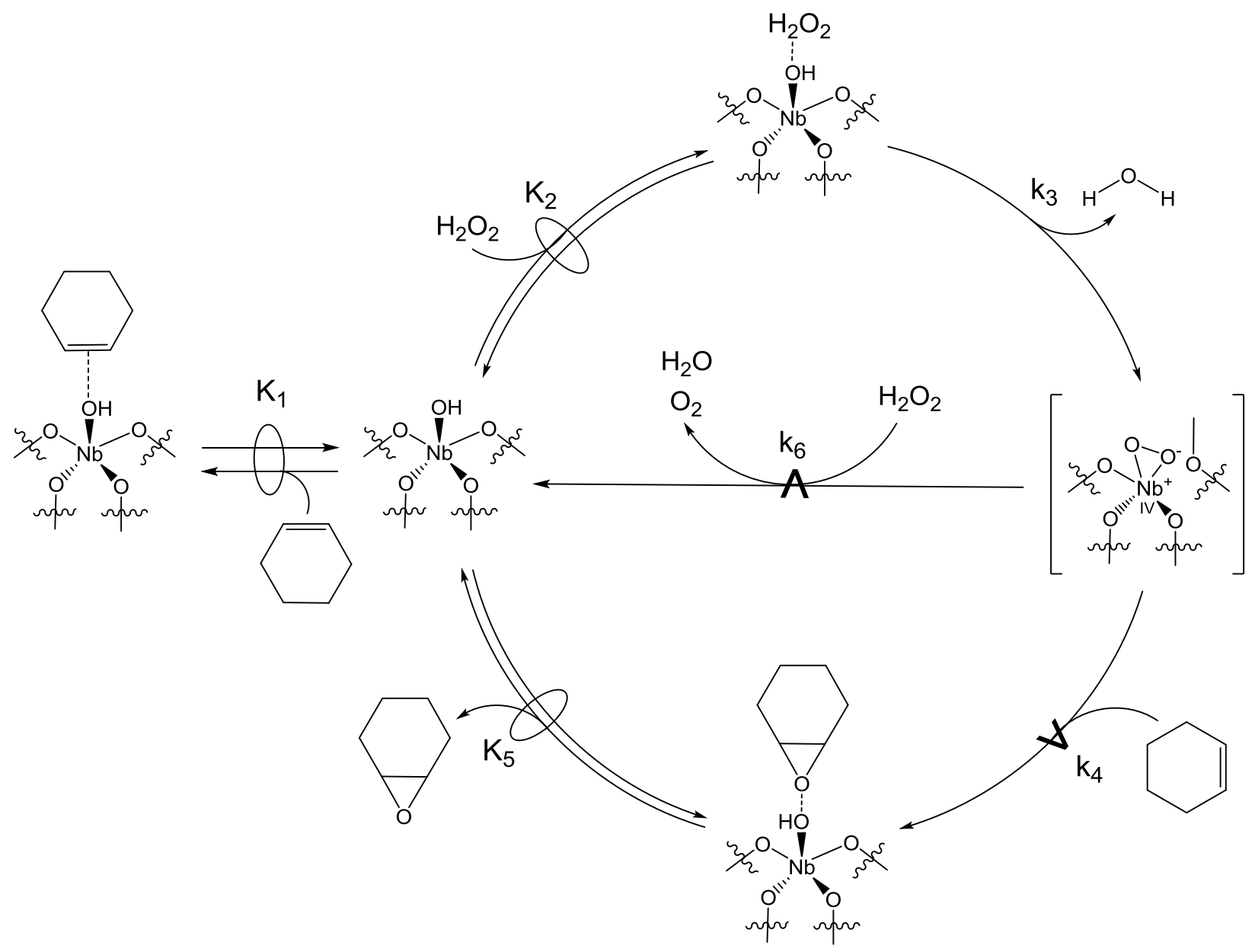

Scheme 3 depicts our proposed mechanism for the epoxidation of $\mathrm{C}_{6} \mathrm{H}_{10}$ with $\mathrm{H}_{2} \mathrm{O}_{2}$ over $\mathrm{Nb}$ $\beta$. This scheme includes quasi-equilibrated adsorption and desorption of $\mathrm{C}_{6} \mathrm{H}_{10}$ (step 1), $\mathrm{H}_{2} \mathrm{O}_{2}$ (step 2), and $\mathrm{C}_{6} \mathrm{H}_{10} \mathrm{O}$ (step 5), and the irreversible formation of $\mathrm{Nb}^{\mathrm{IV}}-\left(\mathrm{O}_{2}\right)$ (step 3). The epoxidation of $\mathrm{C}_{6} \mathrm{H}_{10}$ (step 4) and the bimolecular decomposition of $\mathrm{H}_{2} \mathrm{O}_{2}$ (step 6) occur in kinetically relevant, irreversible steps that involve $\mathrm{Nb}^{\mathrm{IV}}-\left(\mathrm{O}_{2}\right)$ and $\mathrm{C}_{6} \mathrm{H}_{10}$ or $\mathrm{H}_{2} \mathrm{O}_{2}$ co-reactants, respectively. A Langmuir-Hinshelwood mechanism seems unlikely because the average distance between adjacent $\mathrm{Nb}$ atoms $(2.64 \mathrm{~nm}[78])$ is too large for interaction between adsorbates [79, 
80]. Scheme 3 suggests net $\mathrm{C}_{6} \mathrm{H}_{10} \mathrm{O}$ formation rates $\left(r_{E}\right)$ that depend on the number of $\mathrm{Nb}^{\mathrm{IV}}-\left(\mathrm{O}_{2}\right)$ intermediates and the concentration of $\mathrm{C}_{6} \mathrm{H}_{10}$ in solution as:

$$
r_{E}=k_{4}\left[C_{6} H_{10}\right] \cdot\left[N b^{I V}-\left(O_{2}\right)\right]
$$

where $\left[\mathrm{Nb}^{\mathrm{IV}}-\left(\mathrm{O}_{2}\right)\right]$ is the number of $\mathrm{Nb}^{\mathrm{IV}}-\left(\mathrm{O}_{2}\right)$ species and $\mathrm{k}_{4}$ is the rate constant for the epoxidation of $\mathrm{C}_{6} \mathrm{H}_{10}$ with $\mathrm{Nb}^{\mathrm{IV}}-\left(\mathrm{O}_{2}\right)$. Application of the pseudo-steady state hypothesis (PSSH) to the number of $\mathrm{Nb}^{\mathrm{IV}}-\left(\mathrm{O}_{2}\right)$ complexes yields the following rate expression:

$$
\frac{r_{E}}{[L]}=\frac{k_{3} k_{4} K_{2}\left[C_{6} H_{10}\right] \cdot\left[H_{2} O_{2}\right] \cdot[*]}{\left(k_{4}\left[C_{6} H_{10}\right]+k_{6}\left[H_{2} O_{2}\right]\right)}
$$

where $k_{x}$ and $K_{x}$ are the rate and equilibrium constants, respectively, for each step $x$ (Scheme 3) and [*] is the number of available $\mathrm{Nb}-\mathrm{OH}$ moieties (i.e., active sites) that can bind and react with species in solution (or weakly associate with silica near the active site). An expression for [*] is given from the sum of all likely surface intermediates:

$$
[L]=\left([*]+\left[\mathrm{C}_{6} \mathrm{H}_{10} *\right]+\left[\mathrm{H}_{2} \mathrm{O}_{2} *\right]+\left[\mathrm{Nb}-\left(\mathrm{O}_{2}\right)\right]+\left[\mathrm{C}_{6} \mathrm{H}_{10} \mathrm{O} *\right]\right)
$$

where $[L]$ is the total number of active sites, $\left[\mathrm{Nb}-\left(\mathrm{O}_{2}\right)\right]$ is the pool of $\mathrm{Nb}^{\mathrm{IV}}-\left(\mathrm{O}_{2}\right)$ and Nb${ }^{\mathrm{V}}-\left(\mathrm{O}_{2}\right)$ species, and $\left[\mathrm{C}_{6} \mathrm{H}_{10}{ }^{*}\right],\left[\mathrm{H}_{2} \mathrm{O}_{2} *\right]$, and $\left[\mathrm{C}_{6} \mathrm{H}_{10} \mathrm{O}^{*}\right]$ are the number of adsorbed $\mathrm{C}_{6} \mathrm{H}_{10}, \mathrm{H}_{2} \mathrm{O}_{2}$, and $\mathrm{C}_{6} \mathrm{H}_{10} \mathrm{O}$ species, respectively. Equation 6 can then be re-stated in terms of the rate and equilibrium constants as well as the liquid-phase reactant concentrations by application of the PSSH to each specie:

$$
[L]=\left([*]+K_{1}\left[C_{6} H_{10}\right] \cdot[*]+K_{2}\left[H_{2} O_{2}\right] \cdot[*]+\frac{k_{3} K_{2}\left[H_{2} O_{2}\right] \cdot[*]}{\left(k_{4}\left[C_{6} H_{10}\right]+k_{6}\left[H_{2} O_{2}\right]\right)}+K_{5}\left[C_{6} H_{10} O\right] \cdot[*]\right)
$$


The combination of equations 5 and 7 yield a complete rate expression for $\mathrm{C}_{6} \mathrm{H}_{10} \mathrm{O}$ formation:

$$
\frac{r_{E}}{[L]}=\frac{k_{3} k_{4} K_{2}\left[C_{6} H_{10}\right] \cdot\left[H_{2} O_{2}\right]}{\left(k_{4}\left[C_{6} H_{10}\right]+k_{6}\left[H_{2} O_{2}\right]\right)\left(1+K_{1}\left[C_{6} H_{10}\right]+K_{2}\left[H_{2} O_{2}\right]+\frac{k_{3} K_{2}\left[H_{2} O_{2}\right]}{\left(k_{4}\left[C_{6} H_{10}\right]+k_{6}\left[H_{2} O_{2}\right]\right)}+K_{5}\left[C_{6} H_{10} O\right]\right)}
$$

The form of this full rate equation simplifies in the limit when active sites become saturated with $\mathrm{H}_{2} \mathrm{O}_{2}$-derived intermediates (i.e., $\mathrm{Nb}^{\mathrm{IV}}-\left(\mathrm{O}_{2}\right) / \mathrm{Nb}^{\mathrm{V}}-\left(\mathrm{O}_{2}\right)$ are the MARI) as is expected in the limit of low $\left[\mathrm{C}_{6} \mathrm{H}_{10}\right]:\left[\mathrm{H}_{2} \mathrm{O}_{2}\right]$ reactant ratios:

$$
\frac{r_{E}}{[L]}=k_{4}\left[C_{6} H_{10}\right]
$$

Equation 9 is consistent with the $\mathrm{C}_{6} \mathrm{H}_{10} \mathrm{O}$ formation rates that increase in proportion to $\left[\mathrm{C}_{6} \mathrm{H}_{10}\right]$ at low $\left[\mathrm{C}_{6} \mathrm{H}_{10}\right]$ (Figure $7 \mathrm{a}, 0.01-0.1 \mathrm{M} \mathrm{C}_{6} \mathrm{H}_{10}$ ), and which do not depend on $\left[\mathrm{H}_{2} \mathrm{O}_{2}\right]$ (Figure 8b, 0.5 - $5 \mathrm{mM} \mathrm{H}_{2} \mathrm{O}_{2}, 5 \mathrm{mM} \mathrm{C}_{6} \mathrm{H}_{10}$ ). Turnover rates for epoxidation depend inversely on $\left[\mathrm{C}_{6} \mathrm{H}_{10} \mathrm{O}\right]$ at high $\left[\mathrm{C}_{6} \mathrm{H}_{10}\right]$, because adsorbed $\mathrm{C}_{6} \mathrm{H}_{10} \mathrm{O}$ becomes the MARI at values of $\left[\mathrm{C}_{6} \mathrm{H}_{10}\right]$ greater than 0.5 M. Intuitively, $\mathrm{C}_{6} \mathrm{H}_{10} \mathrm{O}$ becomes the MARI at high $\left[\mathrm{C}_{6} \mathrm{H}_{10}\right]$ only when small amounts of epoxide (present as a reagent contaminant, or upon initial formation of $\mathrm{C}_{6} \mathrm{H}_{10} \mathrm{O}$ ) are present. In this limit, equation 8 simplifies to:

$$
\frac{r_{E}}{[L]}=\frac{k_{3} k_{4} K_{2}\left[C _ { 6 } H _ { 1 0 } \left[\left[H_{2} O_{2}\right]\right.\right.}{\left(k_{4}\left[C_{6} H_{10}\right]+k_{6}\left[H_{2} O_{2}\right]\right)\left[C_{6} H_{10} O\right]}
$$

The denominator in equation 10 shows that the rate of epoxidation when adsorbed $\mathrm{C}_{6} \mathrm{H}_{10} \mathrm{O}$ is the MARI depends on the propensity of $\mathrm{Nb}-\left(\mathrm{O}_{2}\right)^{-}$to epoxidize $\mathrm{C}_{6} \mathrm{H}_{10}\left(k_{4}\left[C_{6} H_{10}\right]\right)$ relative to decompose by reaction with $\mathrm{H}_{2} \mathrm{O}_{2}\left(k_{6}\left[\mathrm{H}_{2} \mathrm{O}_{2}\right]\right)$. 


\subsection{Mechanistic Interpretation for $\mathrm{H}_{2} \mathrm{O}_{2}$ Decomposition over $\mathrm{Nb}-\beta$}

Control experiments show that in the absence of $\mathrm{Nb}-\beta$, no $\mathrm{H}_{2} \mathrm{O}_{2}$ decomposition is observed after $4 \mathrm{~h}$ at $333 \mathrm{~K}$ (data not shown). Values of $\left[\mathrm{H}_{2} \mathrm{O}_{2}\right]$, however, decrease steadily with time when $\mathrm{H}_{2} \mathrm{O}_{2}$ contacts $\mathrm{Nb}-\beta$. The unimolecular decomposition of $\mathrm{H}_{2} \mathrm{O}_{2}$ via a $\mathrm{Nb}^{\mathrm{IV}}-\left(\mathrm{O}_{2}\right)$ intermediate cannot account for $\mathrm{H}_{2} \mathrm{O}_{2}$ consumption, because FTIR (Fig. S11) and UV-vis spectra (Fig. 5b) show that the $\mathrm{Nb}^{\mathrm{IV}}-\left(\mathrm{O}_{2}\right)$ species are stable over multiple hours when they are isolated from liquid-phase $\mathrm{C}_{6} \mathrm{H}_{10}$ and $\mathrm{H}_{2} \mathrm{O}_{2}$. Therefore, $\mathrm{H}_{2} \mathrm{O}_{2}$ decomposition likely occurs through a bimolecular reaction between $\mathrm{Nb}^{\mathrm{IV}}-\left(\mathrm{O}_{2}\right)$ and a liquid-phase $\mathrm{H}_{2} \mathrm{O}_{2}$ molecule [22]. The rate of this reaction follows the form:

$$
r_{D}=k_{6}\left[H_{2} O_{2}\right] \cdot\left[N b^{N}-\left(O_{2}\right)\right]
$$

where $r_{D}$ is the rate of $\mathrm{H}_{2} \mathrm{O}_{2}$ consumption via decomposition over $\mathrm{Nb}-\beta$ and $\mathrm{k}_{6}$ is the rate constant for the bimolecular reaction between $\mathrm{Nb}^{\mathrm{IV}}-\left(\mathrm{O}_{2}\right)$ and a $\mathrm{H}_{2} \mathrm{O}_{2}$ molecule in solution. The expression for total $\mathrm{H}_{2} \mathrm{O}_{2}$ consumption is obtained from the sum of equations 4 and 11 to yield:

$$
r_{\mathrm{H}_{2} \mathrm{O}_{2}}=k_{4}\left[C_{6} H_{10}\right] \cdot\left[N b^{N}-\left(O_{2}\right)\right]+k_{6}\left[H_{2} O_{2}\right] \cdot\left[N b^{N}-\left(O_{2}\right)\right]
$$

where $r_{\mathrm{H}_{2} \mathrm{O}_{2}}$ is the rate of total $\mathrm{H}_{2} \mathrm{O}_{2}$ consumption through epoxidation and decomposition processes. Application of the PSSH to $\mathrm{Nb}^{\mathrm{IV}}-\left(\mathrm{O}_{2}\right)$ (Section 3.2, algebraic manipulation omitted) allows equation 12 to be restated in terms of liquid concentrations as:

$$
\frac{r_{H_{2} O_{2}}}{[L]}=\frac{k_{3} K_{2}\left[H_{2} O_{2}\right]}{\left(1+K_{1}\left[C_{6} H_{10}\right]+K_{2}\left[H_{2} O_{2}\right]+\frac{k_{3} K_{2}\left[H_{2} O_{2}\right]}{\left(k_{4}\left[C_{6} H_{10}\right]+k_{6}\left[H_{2} O_{2}\right]\right)}+K_{5}\left[C_{6} H_{10} O\right]\right)}
$$


Equation 13 shows that the rate of $\mathrm{H}_{2} \mathrm{O}_{2}$ consumption depends only on the rate of $\mathrm{C}_{6} \mathrm{H}_{10}$ epoxidation $\left(k_{4}\left[\mathrm{C}_{6} \mathrm{H}_{10}\right]\right)$ or $\mathrm{H}_{2} \mathrm{O}_{2}$ decomposition $\left(k_{6}\left[\mathrm{H}_{2} \mathrm{O}_{2}\right]\right)$ when surfaces are saturated with $\mathrm{Nb}^{\mathrm{IV}}-\left(\mathrm{O}_{2}\right)$. For all other identities of the MARI, $\mathrm{H}_{2} \mathrm{O}_{2}$ consumption is controlled by the rate of $\mathrm{H}_{2} \mathrm{O}_{2}$ activation at the reactive $\mathrm{Nb}$-centers. This shows that the $\mathrm{H}_{2} \mathrm{O}_{2}$ selectivity for epoxidation can be controlled by reaction at conditions which solely maximize the turnover rate for $\mathrm{C}_{6} \mathrm{H}_{10} \mathrm{O}$ formation.

\section{4 $\mathrm{H}_{2} \mathrm{O}_{2}$ Selectivity for Epoxidation and Mechanistic Implications}

The selective use of $\mathrm{H}_{2} \mathrm{O}_{2}$ for epoxidations is a necessary economic consideration before a catalyst can be adapted for industrial epoxidation chemistries, and consequently requires the ratio of the rates for epoxidation to $\mathrm{H}_{2} \mathrm{O}_{2}$ consumption (i.e., $r_{E} / r_{\mathrm{H}_{2} \mathrm{O}_{2}}$ ) to approach unity (i.e., $100 \%$ selectivity). From the combination of equations 8 and 13, the ratio of the rate of $\mathrm{C}_{6} \mathrm{H}_{10} \mathrm{O}$ formation to that for $\mathrm{H}_{2} \mathrm{O}_{2}$ consumption (Fig. S12) yields the following expression:

$$
\alpha=\frac{r_{E}}{r_{H_{2} O_{2}}}=\frac{k_{4}\left[C_{6} H_{10}\right]}{k_{4}\left[C_{6} H_{10}\right]+k_{6}\left[H_{2} O_{2}\right]}
$$

Equation 14 may be linearized, with respect to inverse $\left[\mathrm{C}_{6} \mathrm{H}_{10}\right]$, by taking the inverse of $\alpha$ to give:

$$
\alpha^{-1}=\frac{r_{H_{2} O_{2}}}{r_{E}}=1+\frac{k_{6}\left[H_{2} O_{2}\right]}{k_{4}\left[C_{6} H_{10}\right]}
$$




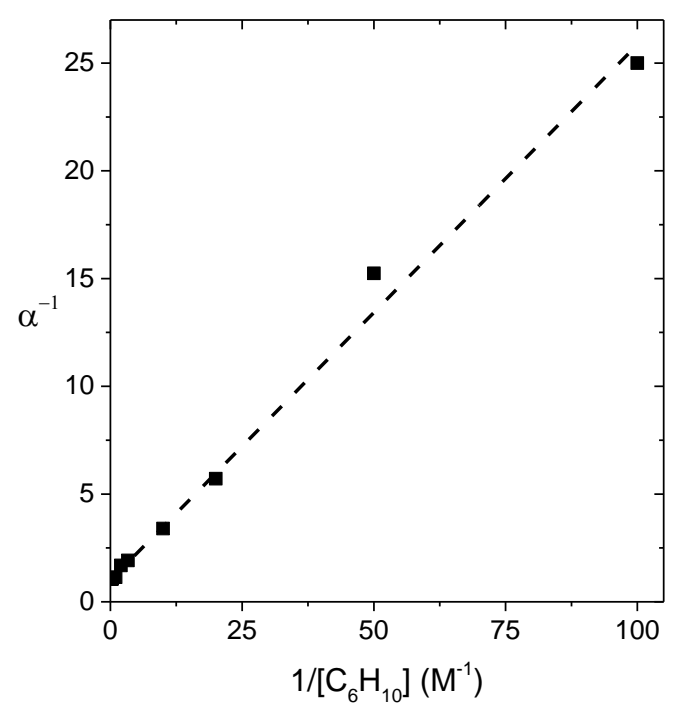

Figure 8. Ratio of total $\mathrm{H}_{2} \mathrm{O}_{2}$ consumption to $\mathrm{C}_{6} \mathrm{H}_{10} \mathrm{O}$ formation as a function of inverse $\mathrm{C}_{6} \mathrm{H}_{10}$ concentration on $\mathrm{Nb}_{1.5} \beta\left(1 \mathrm{mM} \mathrm{H} \mathrm{O}_{2}, 313 \mathrm{~K}\right)$. Dashed line represents linear fit to equation 15 with an $r^{2}$ of 0.995 .

Figure 8 shows values of $\alpha^{-1}$ as a function of inverse $\left[\mathrm{C}_{6} \mathrm{H}_{10}\right]\left(1 \mathrm{mM}\left[\mathrm{H}_{2} \mathrm{O}_{2}\right], 313 \mathrm{~K}\right)$. The value of the slope (found to be 0.25 ) shows that $k_{4}\left[C_{6} H_{10}\right]>>k_{6}\left[H_{2} O_{2}\right]$ at high $\left[\mathrm{C}_{6} \mathrm{H}_{10}\right](1-5 \mathrm{M}$ ), which indicates that in the limit of high $\left[\mathrm{C}_{6} \mathrm{H}_{10}\right]:\left[\mathrm{H}_{2} \mathrm{O}_{2}\right]$, equation 10 can be approximated as follows:

$$
\frac{r_{E}}{[L]}=\frac{k_{3} K_{2}\left[H_{2} O_{2}\right]}{\left[C_{6} H_{10} O\right]}
$$

which qualitatively agrees with the trends observed in Figures $7 \mathrm{a}$ (i.e., $\mathrm{r}_{\mathrm{E}} \sim\left[\mathrm{C}_{6} \mathrm{H}_{10}\right]^{0} \cdot\left[\mathrm{C}_{6} \mathrm{H}_{10} \mathrm{O}\right]^{-1}$ ) and $7 \mathrm{~b}\left(\mathrm{r}_{\mathrm{E}} \sim\left[\mathrm{H}_{2} \mathrm{O}_{2}\right]^{1}\right)$ when $\left[\mathrm{C}_{6} \mathrm{H}_{10}\right]:\left[\mathrm{H}_{2} \mathrm{O}_{2}\right]$ reactant ratios are large. Overall, the proposed mechanism (Scheme 3) agrees with the spectroscopic observations in Figures 3-6 and the rate data presented in Figures 7 and 8 .

\subsection{Epoxidation and Decomposition Activation Enthalpies $\left(\Delta \mathbf{H}^{\ddagger}\right)$ and Entropies $\left(\Delta \mathbf{S}^{\ddagger}\right)$}


Transition-state theory (TST) provides a theoretical foundation to relate the stability of a reference state (e.g., the most abundant reactive intermediate) to an activated complex that facilitates the reaction (i.e., the transition state) $[4,81]$. Here, the values of apparent activation enthalpies $\left(\Delta \mathrm{H}^{\ddagger}\right)$ and entropies $\left(\Delta \mathrm{S}^{\dagger}\right)$ can be used to compare the relative stability of the transition states that selectively activate $\mathrm{H}_{2} \mathrm{O}_{2}$ and epoxidize an olefin to those that facilitate nonselective $\mathrm{H}_{2} \mathrm{O}_{2}$ decomposition. TST, in conjunction with our proposed mechanism (Scheme 3), proposes that the reactant species (e.g., $\mathrm{Nb}^{\mathrm{IV}}-\left(\mathrm{O}_{2}\right)$ and $\mathrm{C}_{6} \mathrm{H}_{10}$ ) exist in equilibrium with the transition state (i.e., $\left.\mathrm{Nb}^{\mathrm{IV}}-\left(\mathrm{O}_{2}\right)-\mathrm{C}_{6} \mathrm{H}_{10^{+}}\right)$for the elementary step for epoxidation (i.e., Scheme 3, step 4) [54].

Scheme 4. Thermochemical cycle depicting changes in free energy in the reaction sequence shown in Scheme 3, which forms transition states for epoxide formation and $\mathrm{H}_{2} \mathrm{O}_{2}$ decomposition through reaction with $\mathrm{Nb}^{\mathrm{IV}}-\left(\mathrm{O}_{2}\right)$.

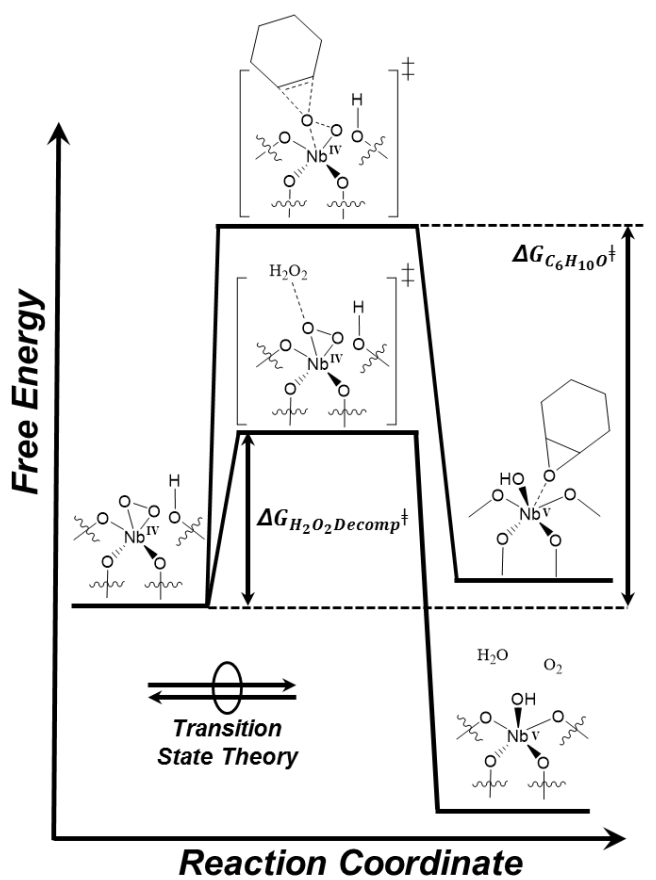

The combined equilibria are expressed as: 


$$
\begin{gathered}
\left.N b^{I V}-\left(O_{2}\right)+C_{6} H_{10} \stackrel{K_{E}^{*}}{\rightleftarrows} \mid N b-\left(O_{2}\right)-C_{6} H_{10}{ }^{\ddagger}\right\rfloor \\
\left.N b^{I V}-\left(O_{2}\right)+H_{2} O_{2} \stackrel{K^{*}}{\Longleftrightarrow} \mid N b-\left(O_{2}\right)-H_{2} O_{2}^{*}\right\rfloor
\end{gathered}
$$

where $\mathrm{K}_{\mathrm{E}}^{\ddagger}$ and $\mathrm{K}_{\mathrm{D}}^{\ddagger}$ are the transition state equilibrium constants for $\mathrm{C}_{6} \mathrm{H}_{10} \mathrm{O}$ formation and $\mathrm{H}_{2} \mathrm{O}_{2}$ decomposition, respectively. Expression of the rate of epoxidation and $\mathrm{H}_{2} \mathrm{O}_{2}$ decomposition in terms of the number of transition states (i.e., $\left[\mathrm{Nb}^{\mathrm{IV}}-\left(\mathrm{O}_{2}\right)-\mathrm{C}_{6} \mathrm{H}_{10}{ }^{\dagger}\right]$ or $\left[\mathrm{Nb}^{\mathrm{IV}}-\left(\mathrm{O}_{2}\right)-\mathrm{H}_{2} \mathrm{O}_{2}^{\ddagger}\right]$ ), yields:

$$
\begin{aligned}
& \frac{r_{E}}{[L]}=\frac{k_{B} T}{h}\left[N b^{N}-\left(O_{2}\right)-C_{6} H_{10}^{\ddagger}\right] \\
& \frac{r_{D}}{[L]}=\frac{k_{B} T}{h}\left[N b^{N}-\left(O_{2}\right)-H_{2} O_{2}^{\ddagger}\right]
\end{aligned}
$$

where $\mathrm{T}$ is the temperature in Kelvin, and $\mathrm{k}_{\mathrm{B}}$ and $\mathrm{h}$ are Boltzmann's and Planck's constant, respectively. When the rates of reaction are measured on $\mathrm{Nb}^{\mathrm{IV}}-\left(\mathrm{O}_{2}\right) / \mathrm{Nb}^{\mathrm{V}}-\left(\mathrm{O}_{2}\right)$ saturated surfaces, the equations 19 and 20 may be expressed in terms of reactant concentrations and transition-state equilibrium constants:

$$
\begin{aligned}
& \frac{r_{E}}{[L]}=\frac{k_{B} T}{h} K_{E}^{\ddagger}\left[C_{6} H_{10}\right] \\
& \frac{r_{D}}{[L]}=\frac{k_{B} T}{h} K_{D}^{\ddagger}\left[H_{2} O_{2}\right]
\end{aligned}
$$

which allows the values of $\mathrm{K}_{\mathrm{E}}^{\ddagger}$ and $\mathrm{K}_{\mathrm{D}}^{\ddagger}$ to be determined by measuring the turnover rates for each reaction pathway at a given temperature. Values of $K_{x}^{\ddagger}$ may be expressed in terms of the 
apparent free energy change of activation $\left(\Delta \mathrm{G}^{\dagger}\right.$ ), and subsequently $\Delta \mathrm{H}^{\ddagger}$ and $\Delta \mathrm{S}^{\ddagger}$ (from the relationship $\left.\Delta \mathrm{G}^{\ddagger}=\Delta \mathrm{H}^{\ddagger}-\mathrm{T} \Delta \mathrm{S}^{\ddagger}\right)$ :

$$
K_{x}^{\ddagger}=e^{-\Delta G_{x}^{\ddagger} / R T}=e^{-\Delta H_{x}^{\ddagger} / R T} e^{\Delta S_{x}^{\ddagger} / R}
$$

where $\mathrm{R}$ is the ideal gas constant and the subscript $\mathrm{x}$ indicates that the associated variable corresponds to the formation of product $x$ (i.e., epoxidation (E) for $\mathrm{C}_{6} \mathrm{H}_{10} \mathrm{O}$ and decomposition (D) for $\mathrm{H}_{2} \mathrm{O}$ ). Figure $\mathrm{S} 13$ shows measured values for $\mathrm{K}_{\mathrm{E}}^{\ddagger}$ and $\mathrm{K}_{\mathrm{D}}^{\ddagger}$ as functions of inverse temperature, which are used to determine experimental values for $\Delta \mathrm{H}_{\mathrm{E}}^{\star}, \Delta \mathrm{H}_{\mathrm{D}}^{\ddagger}, \Delta \mathrm{S}_{\mathrm{E}}^{\star}$, and $\Delta \mathrm{S}_{\mathrm{D}}^{\ddagger}$ by combining equations $21-23$.

Table 4. Catalyst Activation Enthalpies and Entropies for $\mathrm{C}_{6} \mathrm{H}_{10}$ Epoxidation and $\mathrm{H}_{2} \mathrm{O}_{2}$ Decomposition on a $\mathrm{Nb}^{\mathrm{IV}}-\left(\mathrm{O}_{2}\right) / \mathrm{Nb}^{\mathrm{V}}-\left(\mathrm{O}_{2}\right)$ Covered Surface. ${ }^{\mathrm{a}}$

\begin{tabular}{ccccc}
\hline Catalyst & $\Delta \mathrm{H}_{\mathrm{E}}^{\ddagger}\left(\mathrm{kJ} \mathrm{mol}^{-1}\right)$ & $\Delta \mathrm{S}_{\mathrm{E}}^{\ddagger}\left(\mathrm{J} \mathrm{mol}^{-1} \mathrm{~K}^{-1}\right)$ & $\Delta \mathrm{H}_{\mathrm{D}}^{\ddagger}\left(\mathrm{kJ} \mathrm{mol}^{-1}\right)$ & $\Delta \mathrm{S}_{\mathrm{D}}^{\ddagger}\left(\mathrm{J} \mathrm{mol}^{-1} \mathrm{~K}^{-1}\right)$ \\
\hline $\mathrm{Nb}_{1.5}$-BEA & $72 \pm 3$ & $-35 \pm 21$ & $45 \pm 2$ & $-91 \pm 30$
\end{tabular}

${ }^{a}$ Activation enthalpies and entropies were calculated from measured transition-state equilibrium constants $\left(\mathrm{K}^{*}\right.$, Figure S13) and equation 23. Error in activation enthalpies and entropies was estimated by the linear regression analysis performed to fit the Eyring equation to the data in Fig. S13.

Table 4 shows values of $\Delta \mathrm{H}_{\mathrm{E}}^{*}, \Delta \mathrm{H}_{\mathrm{D}}^{\star}, \Delta \mathrm{S}_{\mathrm{E}}^{\star}$, and $\Delta \mathrm{S}_{\mathrm{D}}^{\star}$ for $\mathrm{Nb}-\beta$ calculated from $\mathrm{K}_{\mathrm{E}}^{\star}$ and $\mathrm{K}_{\mathrm{D}}^{\star}$ (Fig. S13, equations 21 and 22). $\Delta \mathrm{H}^{\ddagger}$ values for epoxidation $\left(72 \mathrm{~kJ} \mathrm{~mol}^{-1}\right)$ are $27 \mathrm{~kJ} \mathrm{~mol}^{-1}$ higher than for $\mathrm{H}_{2} \mathrm{O}_{2}$ decomposition (45 $\mathrm{kJ} \mathrm{mol}^{-1}$ ), which show that decomposition of $\mathrm{H}_{2} \mathrm{O}_{2}$ is enthalpically favored to that of $\mathrm{C}_{6} \mathrm{H}_{10}$ epoxidation. Alternatively, $\Delta \mathrm{S}^{*}$ values for $\mathrm{H}_{2} \mathrm{O}_{2}$ decomposition (-91 $\mathrm{J} \mathrm{mol}^{-1} \mathrm{~K}^{-1}$ ) are significantly more negative than for $\mathrm{C}_{6} \mathrm{H}_{10}$ epoxidation (-35 $\mathrm{J}$ 
$\mathrm{mol}^{-1} \mathrm{~K}^{-1}$ ), which makes epoxidation entropically favored in comparison to $\mathrm{H}_{2} \mathrm{O}_{2}$ decomposition. Interestingly, epoxidation is entropically favored over $\mathrm{H}_{2} \mathrm{O}_{2}$ decomposition, which suggests $\mathrm{H}_{2} \mathrm{O}_{2}$ selectivity is maximized by running the reaction at higher temperatures. This finding is not immediately intuitive as $\mathrm{H}_{2} \mathrm{O}_{2}$ and $\mathrm{H}_{2} \mathrm{O}_{2}$-derived intermediates are generally thought to decompose rapidly (in comparison to many other species) at elevated temperatures. Besides the non-intuitive differences in $\Delta \mathrm{H}^{*}$, the selectivities for $\mathrm{H}_{2} \mathrm{O}_{2}$ to epoxidize $\mathrm{C}_{6} \mathrm{H}_{10}$ reflect the ratio of the concentrations of the co-reactants (i.e., $\mathrm{H}_{2} \mathrm{O}_{2}$ or $\mathrm{C}_{6} \mathrm{H}_{10}$ ) for these bimolecular pathways, because the fate of the $\mathrm{Nb}^{\mathrm{IV}}-\left(\mathrm{O}_{2}\right)$ depends on the likelihood that this reactive intermediate first encounter liquid-phase $\mathrm{C}_{6} \mathrm{H}_{10}$ or $\mathrm{H}_{2} \mathrm{O}_{2}$. 


\subsection{Conclusions}

Ex situ XPS and in situ UV-vis and FTIR spectra reveal two types of metal-bound oxygen species (i.e., $\mathrm{Nb}^{\mathrm{IV}}-\left(\mathrm{O}_{2}\right)$ and $\mathrm{Nb}^{\mathrm{V}}-\left(\mathrm{O}_{2}\right)$ ) that form upon the irreversible activation of $\mathrm{H}_{2} \mathrm{O}_{2}$ over $\mathrm{Nb}-\beta$. Time-resolved UV-vis spectra acquired in situ reveal that $\mathrm{Nb}^{\mathrm{IV}}-\left(\mathrm{O}_{2}\right)$ (i.e., superoxide) species is responsible for olefin epoxidation, which is further confirmed by the isomeric distribution (cis:trans $\sim$ ) of the epoxide products from reaction with cis-stilbene. Collectively, these data, when combined with the observed dependencies of reaction rates on $\mathrm{C}_{6} \mathrm{H}_{10}, \mathrm{H}_{2} \mathrm{O}_{2}$, and $\mathrm{C}_{6} \mathrm{H}_{10} \mathrm{O}$ provide a complete mechanistic understanding of olefin epoxidation over $\mathrm{Nb}-\beta$ that is consistent with an Eley-Rideal mechanism and indicate that the reactive form of oxygen (i.e., $\left.\mathrm{Nb}^{\mathrm{IV}}-\left(\mathrm{O}_{2}\right)\right)$ forms irreversibly under reaction conditions. Additionally, this mechanism also accurately describes the dependence of epoxidation rates on reactant concentrations observed in previous studies on similar Ti- and Ta-based catalysts, which had assumed the quasi-equilibrated formation of the reactive intermediate. Calculated values of $\Delta \mathrm{H}^{\star}$ and $\Delta \mathrm{S}^{\ddagger}$ for $\mathrm{C}_{6} \mathrm{H}_{10} \mathrm{O}$ formation and $\mathrm{H}_{2} \mathrm{O}_{2}$ decomposition demonstrate that epoxide formation is enthalpically disfavored, which suggests that $\mathrm{H}_{2} \mathrm{O}_{2}$ selectivity towards epoxidation is maximized at higher temperatures. Overall, these results can aid in the rational design of increasingly selective catalysts for olefin epoxidation with $\mathrm{H}_{2} \mathrm{O}_{2}$ and provide methods to probe other metals to observe possible periodic trends in reactivity. Ongoing investigations in our group extend this mechanistic understanding of olefin epoxidation over M- $\beta$ catalysts to the rational design of increasingly selective and active catalysts by probing periodic trends and the importance of the elemental identity of the substituted metal atom. 


\subsection{Supporting Information}

Additional catalyst characterization ( $\mathrm{p}$-XRD, DRUV-vis, solid-state NMR), Madon-Boudart criterion, detection of metal-bound oxygen species (in situ DRUV-vis and FTIR), MES-PSD data analysis derivation, derivation of previously proposed epoxidation and $\mathrm{H}_{2} \mathrm{O}_{2}$ decomposition mechanisms, $\mathrm{H}_{2} \mathrm{O}_{2}$ selectivity data, temperature-dependence data

\subsection{Acknowledgements}

The authors acknowledge Ms. Megan Witzke and Mr. Neil Wilson for insightful discussions, feedback, and proofreading of the manuscript. We thank Dr. Damien Guironnet (UIUC) for use of equipment used in part for the synthesis of $\mathrm{Nb}-\beta$, the preparation of $\mathrm{H}_{2} \mathrm{O}_{2}$-activated $\mathrm{Nb}-\beta$, and ATR-IR for $\mathrm{Nb}-\beta$ and Si- $\beta$ measurements. We thank Dr. Andre Sutrisno and the School of

Chemical Sciences NMR lab for acquisition of the ${ }^{1} \mathrm{H}$ and ${ }^{29} \mathrm{Si}$ solid-state NMR spectra on Nb- $\beta$. We thank Dr. Rick Haasch for acquisition of the XPS spectra on Nb- $\beta$ materials. This work was carried out in part in the Frederick Seitz Materials Research Laboratory Central Research Facilities, University of Illinois. DTB was supported in part by the National Defense Science and Engineering Graduate (NDSEG) Fellowship. This material is based upon work supported in part by, the U. S. Army Research Laboratory and the U. S. Army Research Office under grant number W911NF-16-1-0128, and upon work supported by the National Science Foundation grant number CBET-1553137. 


\subsection{References}

[1] W.J. Choi, C.Y. Choi, Production of Chiral Epoxides: Epoxide Hydrolase-catalyzed Enantioselective Hydrolysis, Biotechnol. Bioproc. Eng., 10 (2005) 167-179.

[2] D. Lehmhus, M. Busse, A. Herrmann, K. Kayvantash, Structural Materials and Processes in Transportation, Wiley-VCH, Germany, 2013.

[3] Subramanian, M. Polymer Testing: New Instrumental Methods; Momentum Press: New York, NY, 2012.

[4] Anslyn, E. V.; Dougherty, D. A. Modern Physical Organic Chemistry; University Science, 2005.

[5] Allyl Compounds. In Ullmann's Encyclopedia of Industrial Chemistry; Wiley-VCH: Weinheim, Germany, 2012.

[6] Epoxides. In Ullmann's Encyclopedia of Industrial Chemistry; Wiley-VCH: Weinheim, Germany, 2012.

[7] G. Grigoropoulou, J.H. Clark, J.A. Elings, Recent developments on the epoxidation of alkenes using hydrogen peroxide as an oxidant, Green Chemistry, 5 (2003) 1-7.

[8] United States, Environmental Protection Agency. Catalogue of Hazardous and Solid Waste Publications; Environmental Protection Agency, United States, 1992.

[9] Dilla, W.; Dillenburg, H.; Krebber, H. G.; Ploenissen, E.; Process for treating waste water containing organic and inorganic compounds. U.S. Patent 5478472, Dec 26, 1995.

[10] USP Technologies: How much does H2O2 cost? http://www.h2o2.com/faqs/FaqDetail.aspx?fId=25 (accessed June 1, 2016)

[11] N.M. Wilson, D.T. Bregante, P. Priyadarshini, D.W. Flaherty, RSC: Catalysis, 29 (2016) Accepted.

[12] C. De Ruiter, J.H. Wold, U.A. Brinkman, R.W. Frei, Design and Evaluation of a Sandwhich Phase Separation for on-line Liquid/Liquid Extraction, Anal. Chim. Acta, 192 (1987) 267-275.

[13] K. Backstrom, L.G. Danielsson, L. Nord, Design and Evaluation of a New Phase Separator for Liquid/Liquid Extraction in Flow Systems, Anal. Chim. Acta, 169 (1985) 4349.

[14] M.C.A. van Vliet, D. Mandelli, I.W.C.E. Arends, U. Schuchardt, R.A. Sheldon, Alumina: a cheap, active and selective catalyst for epoxidations with (aqueous) hydrogen peroxide, Green Chem., 3 (2001) 243-246.

[15] D. Mandelli, M.C.A. van Vliet, R.A. Sheldon, U. Schuchardt, Alumina-catalyzed alkene epoxidation with hydrogen peroxide, Appl. Catal., A, 219 (2001) 209-213.

[16] R.L. Brutchey, D.A. Ruddy, L.K. Andersen, T.D. Tilley, Influence of Surface Modification of Ti-SBA15 Catalysts on the Epoxidation Mechanism for Cyclohexene with Aqueous Hydrogen Peroxide, Langmuir, 21 (2005) 9576-9583.

[17] I. Schmidt, A. Krogh, K. Wienberg, A. Carlsson, M. Brorson, C.J.H. Jacobsen, Catalytic epoxidation of alkenes with hydrogen peroxide over first mesoporous titanium-containing zeolite, Chem. Commun., (2000) 2157-2158.

[18] W. Fan, P. Wu, S. Namba, T. Tatsumi, Synthesis and catalytic properties of a new titanosilicate molecular sieve with the structure analogous to MWW-type lamellar precursor, J. Catal., 243 (2006) 183-191.

[19] D. Prasetyoko, Z. Ramli, S. Endud, H. Nur, Enhancement of Catalytic Activation of Titanosilicalite-1 Sulfated Zirconia Combination Towards Epoxidation of 1-Octene with Aqueous Hydrogen Peroxide, React. Kinet. Catal. Lett., 86 (2005) 83-89. 
[20] N.E. Thornburg, A.B. Thompson, J.M. Notestein, Periodic Trends in Highly Dispersed Groups IV and V Supported Metal Oxide Catalysts for Alkene Epoxidation with $\mathrm{H} 2 \mathrm{O} 2$, ACS Catal., 5 (2015) 5077-5088.

[21] D.A. Ruddy, T.D. Tilley, Kinetics and Mechanism of Olefin Epoxidation with Aqueous H2O2 and a Highly Selective Surface-Modified TaSBA15 Heterogeneous Catalyst, J. Am. Chem. Soc., 130 (2008) 11088-11096.

[22] N. Morlanés, J.M. Notestein, Kinetic study of cyclooctene epoxidation with aqueous hydrogen peroxide over silica-supported calixarene-Ta(V), Appl. Catal. A, 1, 387 (2010) 4554.

[23] N. Morlanés, J.M. Notestein, Grafted Ta-calixarenes: Tunable, selective catalysts for direct olefin epoxidation with aqueous hydrogen peroxide, J. Catal., 275 (2010) 191-201.

[24] I.D. Ivanchikova, N.V. Maksimchuk, I.Y. Skobelev, V.V. Kaichev, O.A. Kholdeeva, Mesoporous niobium-silicates prepared by evaporation-induced self-assembly as catalysts for selective oxidations with aqueous H2O2, J. Catal., 332 (2015) 138-148.

[25] A. Aronne, M. Turco, G. Bagnasco, G. Ramis, E. Santacesaria, M. Di Serio, E. Marenna, M. Bevilacqua, C. Cammarano, E. Fanelli, Gel derived niobium-silicon mixed oxides: Characterization and catalytic activity for cyclooctene epoxidation, Applied Catalysis A: General, 347 (2008) 179-185.

[26] F. Tielens, T. Shishido, S. Dzwigaj, What Do the Niobium Framework Sites Look Like in Redox Zeolites? A Combined Theoretical and Experimental Investigation, J. Phys. Chem. C, 114 (2010) 3140-3147.

[27] C. Hammond, S. Conrad, I. Hermans, Simple and scalable preparation of highly active Lewis acidic Sn-beta, Angew. Chem. Int. Ed. Engl., 51 (2012) 11736-11739.

[28] Y. Wang, J.D. Lewis, Y. Román-Leshkov, Synthesis of Itaconic Acid Ester Analogues via Self-Aldol Condensation of Ethyl Pyruvate Catalyzed by Hafnium BEA Zeolites, ACS Catal., (2016) 2739-2744.

[29] W.R. Gunther, V.K. Michaelis, M.A. Caporini, R.G. Griffin, Y. Roman-Leshkov, Dynamic nuclear polarization NMR enables the analysis of Sn-Beta zeolite prepared with natural abundance (1)(1)(9)Sn precursors, J. Am. Chem. Soc., 136 (2014) 6219-6222.

[30] P. Wolf, C. Hammond, S. Conrad, I. Hermans, Post-synthetic preparation of Sn-, Ti- and Zr-beta: a facile route to water tolerant, highly active Lewis acidic zeolites, Dalton Trans., 43 (2014) 4514-4519.

[31] M.G. Clerici, P. Ingallina, Epoxidation of Lower Olefins with Hydrogen Peroxide and Titanium Silicalite, J. Catal., 140 (1993) 71-83.

[32] M.G. Clerici, G. Bellussi, U. Romano, Synthesis of Propylene Oxide from Propylene and Hydrogen Peroxide Catalyzed by Titanium Silicalite, J. Catal., 129 (1991) 159-167.

[33] T.A. Nijhuis, M. Makkee, J.A. Moulijn, B.M. Weckhuysen, The Production of Propene oxide: Catalytic Processes and Recent Developments, Ind. Eng. Chem. Res., 45 (2006) 34473459.

[34] E.L. First, C.E. Gounaris, J. Wei, C.A. Floudas, Computational characterization of zeolite porous networks: an automatec approach, Phys. Chem. Chem. Phys., 13 (2011) 1733917358.

[35] C.B. Dartt, M.E. Davis, Characterization and catalytic activity of titanium containing SSZ-33 and aluminum-free zeolite beta, Appl. Catal., A, 143 (1996) 53-73. 
[36] B. Tang, W. Dai, X. Sun, N. Guan, L. Li, M. Hunger, A procedure for the preparation of Ti-Beta zeolites for catalytic epoxidation with hydrogen peroxide, Green Chem., 16 (2014) 2281.

[37] S. Dzwigaj, M.J. Peltre, P. Massiani, A. Davidson, M. Che, T. Sen, S. Sivasanker, Incorporation of vanadium species in a dealuminated b zeolite, Chem. Comm., (1998) 87-88

[38] D.T. Bregante, D.W. Flaherty, Kinetic and Spectroscopic Evidence for Periodic Trends in Olefin Epoxidation over Supported Group IV and V Catalysts, To be submitted.

[39] H. Gao, G. Lu, J. Suo, S. Li, Epoxidation of allyl chloride with hydrogen peroxide catalyzed by titanium silicalite 1, Appl. Catal., A, 138 (1996) 27.

[40] D.A. Ruddy, T.D. Tilley, Highly selective olefin epoxidation with aqueous $\mathrm{H} 2 \mathrm{O} 2$ over surface-modified TaSBA15 prepared via the TMP method, Chem. Commun., (2007) 3350.

[41] A. Escobedo Morales, E. Sanchez Mora, U. Pal, Use of diffuse reflectance spectroscopy for optical characterization of un-supported nanostructures, Rev. Mex. Fis. E., 53 (2007) 1822.

[42] Y. Zhao, X. Zhou, L. Ye, S.C.E. Tsang, Nanostructured Nb2O5catalysts, Nano Rev., 3 (2012).

[43] S. Dzwigaj, Y. Millot, C. Méthivier, M. Che, Incorporation of Nb(V) into BEA zeolite investigated by XRD, NMR, IR, DR UV-vis, and XPS, Microporous Mesoporous Mater., 130 (2010) 162-166.

[44] V.L. Sushkevich, I.I. Ivanova, S. Tolborg, E. Taarning, Meerwein-Ponndorf-VerleyOppenauer reaction of crotonaldehyde with ethanol over $\mathrm{Zr}$-containing catalysts, J. Catal., 316 (2014) 121-129.

[45] S. Dzwigaj, Y. Millot, M. Che, Ta(V)-Single Site BEA Zeolite by Two-Step Postsynthesis Method: Preparation and Characterization, Catal. Lett., 135 (2010) 169-174.

[46] International Zeolite Association: Verified Syntheses of Zeolitic Materials: Characterization by IR Spectroscopy http://www.izaonline.org/synthesis/VS_2ndEd/IR_Spectroscopy.htm (accessed October 12, 2016)

[47] A. Corma, F.X. Llabre's i Xamena, C. Prestipino, M. Renz, S. Valencia, Water Resistant, Catalytically Active $\mathrm{Nb}$ and $\mathrm{Ta}$ Isolated Lewis Acid Sites, Homogeneously Distributed by Direct Synthesis in a Beta Zeolite, J. Phys. Chem. C, 113 (2009) 11306-11315.

[48] L.J. Burcham, J. Datka, I.E. Wachs, In Situ Vibrational Spectroscopy Studies of Supported Niobium Oxide Catalysts, J. Phys. Chem. B, 103 (1999) 6015-6024.

[49] S. Roy, K. Bakhmutsky, E. Mahmoud, R.F. Lobo, R.J. Gorte, Probing Lewis Acid Sites in Sn-Beta Zeolite, ACS Catal., 3 (2013) 573-580.

[50] V.L. Sushkevich, A. Vimont, A. Travert, I.I. Ivanova, Spectroscopic Evidence for Open and Closed Lewis Acid Sites in ZrBEA Zeolites, J. Phys. Chem. C, 119 (2015) 17633-17639.

[51] J. Wang, V.F. Kispersky, W. Nicholas Delgass, F.H. Ribeiro, Determination of the Au active site and surface active species via operando transmission FTIR and isotopic transient experiments on 2.3wt.\% Au/TiO2 for the WGS reaction, J. Catal., 289 (2012) 171-178.

[52] M. Boronat, P. Concepcion, A. Corma, M.T. Navarro, M. Renz, S. Valencia, Reactivity in the confined spaces of zeolites: the interplay between spectroscopy and theory to develop structure-activity relationships for catalysis, Phys. Chem. Chem. Phys., 11 (2009) 2876.

[53] A.N. Baga, A. Johnson, N.B. Nazhat, R.A. Saadalla-Nazhat, A Simple Spectrophotometric Determination of Hydrogen Peroxide at Low Concentrations in Aqueous Solution, Anal. Chim. Acta, 204 (1988) 349-353. 
[54] N.M. Wilson, D.W. Flaherty, Mechanism for the Direct Synthesis of H2O2 on Pd Clusters: Heterolytic Reaction Pathways at the Liquid-Solid Interface, J. Am. Chem. Soc., 138 (2016) 574-586.

[55] R.J. Madon, M. Boudart, Experimental Criterion for the Absence of Artifacts in the Measurement of Rates of Heterogeneous Catalytic Reactions, Ind. Eng. Chem. Fundam., 21 (1982) 438-447.

[56] G. Coudurier, C. Naccache, J.C. Vedrine, Uses of I.R. Spectroscopy in identifying ZSM Zeolite Structure J. Chem. Soc. Chem. Commun., (1982) 1413-1415.

[57] H. Miessner, H. Kosslick, U. Lohse, B. Parlitz, V. Tuan, Characterization of Highly Dealuminated Faujasite-Type Zeolites: Ultrastable Zeolite Y and ZSM-20, J. Phys. Chem., 97 (1993) 9741-9748.

[58] A. Urakawa, T. Bürgi, A. Baiker, Sensitivity enhancement and dynamic behavior analysis by modulation excitation spectroscopy: Principle and application in heterogeneous catalysis, Chem. Eng. Sci., 63 (2008) 4902-4909.

[59] P.A. Giguere, K.B. Harvey, On the Infrared Absorption of Water and Heavy WAter in Condense States., Can. J. Chem., 34 (1956) 798.

[60] W. Lin, H. Frei, Photochemical and FT-IR Probing of the Active Site of Hydrogen Peroxide in Ti Silicalite Sieve, J. Am. Chem. Soc., 124 (2002) 9292-9298.

[61] S. Bordiga, A. Damin, F. Bonino, G. Ricchiardi, C. Lamberti, A. Zecchina, The Structure of the Peroxo Species in the TS-1 Catalyst as Investigated by Resonant Raman Spectroscopy, Angew. Chem. Int. Ed. Engl., 41 (2002) 4734.

[62] C. Chen, H. Yuan, H. Wang, Y. Yao, W. Ma, J. Chen, Z. Hou, Highly Efficient Epoxidation of Allylic Alcohols with Hydrogen Peroxide Catalyzed by Peroxoniobate-Based Ionic Liquids, ACS Catal., 6 (2016) 3354-3364.

[63] B. Notari, Microporous Crystalline Titanium Silicates, Adv. Catal., 41 (1996) 253-334.

[64] J.J. Bravo-Suárez, K.K. Bando, J. Lu, M. Haruta, T. Fujitani, S.T. Oyama, Transient Technique for Identification of True Reaction Intermediates: Hydroperoxide Species in Propylene Epoxidation on Gold/Titanosilicate Catalysts by X-ray Absorption Fine Structure Spectroscopy, J. Phys. Chem. C, 112 (2008) 1115-1123.

[65] F. Bonino, A. Damin, G. Ricchiardi, M. Ricci, G. Spano, R. D'Aloisio, A. Zecchina, C. Lamberti, C. Prestipino, S. Bordiga, Ti-Peroxo Species in the Ts-1/H2O2/H2O System, J. Phys. Chem. B, 108 (2008) 3573-3583.

[66] D. Srinivas, P. Manikandan, S.C. Laha, R. Kumar, P. Ratnasamy, Reactive oxo-titanium species in titanosilicate molecular sieves: EPR investigations and structure-activity correlations, J. Catal., 217 (2003) 160-171.

[67] V.N. Shetti, P. Manikandan, D. Srinivas, P. Ratnasamy, Reactive oxygen species in epoxidation reactions over titanosilicate molecular sieves, J. Catal., 216 (2003) 461-467.

[68] L. Wang, G. Xiong, J. Su, P. Li, H. Guo, In Situ UV Raman Spectroscopic Study on the Reaction Intermediates for Propylene Epoxidation on TS-1, J. Phys. Chem. C, 116 (2012) 9122-9131.

[69] M. Ziolek, I. Sobczak, P. Decyk, K. Sobańska, P. Pietrzyk, Z. Sojka, Search for reactive intermediates in catalytic oxidation with hydrogen peroxide over amorphous niobium(V) and tantalum(V) oxides, Appl. Catal. B, 164 (2015) 288-296.

[70] J. Guzman, S. Carrettin, A. Corma, Spectroscopic Evidence for the Supploy of REactive Oxygen during CO Oxidation, J. Am. Chem. Soc., 127 (2005) 3286. 
[71] R.Q. Long, H.L. Wan, In situ confocal microprobe Raman spectroscopy study ofCeO2 catalyst for the oxidative coupling of methane, J. Chem. Soc., Faraday Trans., 93 (1997) 355.

[72] M. Nakayama, M. Xue, W. An, P. Liu, M.G. White, Influence of Cluster-support Interactions on Reactivity of Size-selected NbxOy Clusters, J. Phys. Chem. C, 119 (2015) 14756-14768.

[73] J.F. Marco, J.R. Gancedo, F.J. Berry, The oxidation states of titanium and niobium in compounds of composition SnxNbTiP3O12 $(\mathrm{O}<\mathrm{x}<0.5)$ : an XPS study, Polyhedron, 16 (1997) 2957-2961.

[74] S.E. Stein, IR and Mass Spectra. In NIST Chemistry WebBook; Mallard, W.G.; Linstrom, P.J., Eds. NIST Standard Reference Database Number 69; National Institute of Standards and Technology: Gaithersburg, MD, (February) 2000, Acetonitrile, Cyclohexene, and Cyclohexane (http://webbook.nist.gov).

[75] N.K.K. Raj, A.V. Ramaswamy, P. Manikandan, Oxidation of norbornene over vanadiumsubstituted phosphomolybdic acid catalysts and spectroscopic investigations, J. Mol. Catal. A: Chem., 227 (2005) 37-45.

[76] C.K. Sams, K.A. Jorgensen, Mechanistic Aspects of Vanadium-Catalysed Oxygen Transfer Reactions, Acta Chem. Scand., 49 (1995) 839-847.

[77] R.V. Ottenbacher, D.G. Samsonenko, E.P. Talsi, K.P. Bryliakov, Enantioselective Epoxidations of Olefins with Various Oxidants on Bioinspired Mn Complexes: Evidence for Different Mechanisms and Chiral Additive Amplification, ACS Catal., 6 (2016) 979-988.

[78] Zeolyst: Zeolite Beta http://www.zeolyst.com/our-products/standard-zeolitepowders/zeolite-beta.aspx (accessed June 1, 2016)

[79] D. Murzin, Engineering Catalysis, de Gruyter, Gottingen, Germany, 2013.

[80] L. Arnaut, S. Formosinho, H. Burrows, Chemical Kinetics: From Molecular Structure to Chemical Reactivity, Elsevier, Netherlands, 2007.

[81] D.W. Flaherty, E. Iglesia, Transition-state enthalpy and entropy effects on reactivity and selectivity in hydrogenolysis of n-alkanes, J. Am. Chem. Soc., 135 (2013) 18586-18599. 